\title{
Roles of Integrins and Intracellular Molecules in the Migration and Neuritogenesis of Fetal Cortical Neurons: MEK Regulates Only the Neuritogenesis
}

\author{
Ujjwal K. Rout \\ Departments of Surgery and Physiology and Biophysics, University of Mississippi Medical Center, Room L020, Clinical Service Building, \\ 2500 North State Street, Jackson, MS 39216, USA
}

Correspondence should be addressed to Ujjwal K. Rout; ujjwalrout11@gmail.com

Received 24 August 2012; Accepted 16 December 2012

Academic Editor: Carles Vilarino-Guell

Copyright (C) 2013 Ujjwal K. Rout. This is an open access article distributed under the Creative Commons Attribution License, which permits unrestricted use, distribution, and reproduction in any medium, provided the original work is properly cited.

The roles of integrin subunits and intracellular molecules in regulating the migration and neuritogenesis of neurons isolated from 16.5 gestation days rat fetal cortices were examined using in vitro assays. Results showed that laminin supported the migration of fetal cortical neurons better than fibronectin and that the fetal cortical neurons migrated on laminin using $\beta 1$ and $\alpha 3$ integrin subunits which make up the $\alpha 3 \beta 1$ integrin receptor. On fibronectin, the migration was mediated by $\beta 1$ integrin subunit. Perturbation of src kinase, phospholipase $\mathrm{C}$, or protein kinase $\mathrm{C}$ activity, inhibition of IP3 receptor mediated calcium release, or chelation of intracellular calcium inhibited both migration and neuritogenesis, whereas inhibition of growth factor signaling via MEK inhibited only the neuritogenesis. The detection of $\alpha 1$ and $\alpha 9$ transcripts suggested that the migration of fetal cortical neurons may also be mediated by $\alpha 1 \beta 1$ and $\alpha 9 \beta 1$ integrin receptors. Results showed that calcium may regulate migration and neuritogenesis by maintaining optimum levels of microtubules in the fetal cortical neurons. It is concluded that the fetal cortical neurons are fully equipped with the integrin signaling cascade required for their migration and neuritogenesis, whereas crosstalk between the integrin and growth-factor signaling regulate only the neuritogenesis.

\section{Introduction}

During brain development, postmitotic neurons migrate from their site of origin to distant places, differentiate, and make connections forming different layers of the cortex. Defects in this process results in abnormal neuronal positioning and connections in the brain, which may cause neurobehavioral problems later in life [1]. Neuritogenesis, an early step of neuron differentiation, is the synthesis of multiple growth cone tipped extensions (neurites) that ultimately form the axons and dendrites of neurons [2]. Mechanisms that regulate the migration and differentiation of neurons are not fully understood.

Cell surface integrin receptors, each consisting of an $\alpha$ and a $\beta$ subunit, play critical roles in the glial-guided migration of neurons in the brain [3]. The extracellular domains of the receptor subunits bind with extracellular matrix (ECM) proteins (such as fibronectin and laminin) and the cytosolic domains of $\beta$ subunits interact with kinases, adaptor molecules, and the cytoskeleton [4]. These interactions facilitate the "outside-in" and the "inside-out" signaling across the cell membrane by the integrin heterodimers [5] that may lead to cell migration and neuritogenesis [6].

Integrin receptors with explicit combinations of $\alpha$ and $\beta$ subunits interact with specific ECM proteins [7]. Developing brains express $\beta 1, \alpha 1, \alpha 3, \alpha 4, \alpha 5, \alpha 6$, and $\alpha v$ integrin subunits which may form $\alpha 1 \beta 1, \alpha 3 \beta 1, \alpha 4 \beta 1, \alpha 5 \beta 1, \alpha 6 \beta 1$, and $\alpha v \beta 1$ integrin receptors $[8,9]$. Of all these receptors, the $\alpha 1 \beta 1$, $\alpha 3 \beta 1$, and $\alpha 6 \beta 1$ receptors interact with laminin, whereas $\alpha 4 \beta 1, \alpha 5 \beta 1$, and $\alpha v \beta 1$ receptors interact with fibronectin [7].

Manipulation of integrin subunits $\alpha 3$ and $\alpha 5$ genes in mice causes abnormal positioning of neurons in the cerebral cortex, and nullifying the $\alpha 6$ gene results in cortical laminar defects $[3,10-12]$. These studies suggest that integrin receptors consisting of $\beta 1$ subunit $(\alpha 3 \beta 1, \alpha 5 \beta 1$, and $\alpha 6 \beta 1$ ) are involved in the migration of neurons in the brain. This is also 
in accordance to a large number of reports describing the role of integrin receptors consisting of $\beta 1$ subunit in neuron migration and neuritogenesis [13-16]. However, studies involving the ablation of $\beta 1$ integrin subunit gene in mice [17-20] suggest that this integrin subunit is required for the glial end feet anchorage and is not essential for neuron-glia interactions and glial-guided migration of neurons during brain development. Moreover, additional studies indicate that $\beta 1$ integrin subunit is involved not in the migration but the differentiation of glia and neurons [2, 20-22]. Therefore, to date, the studies on the role of $\beta 1$ subunit containing integrins $(\alpha 3 \beta 1, \alpha 5 \beta 1$, and $\alpha 6 \beta 1)$ in the migration of fetal brain neurons have been largely inconclusive. Experiments with antibodies against integrin subunits or inhibitors of integrin signaling in slice cultures [23-26] are also not free from the indirect effects that may influence the migration and differentiation of neurons.

Therefore, in the present study, neurons were isolated from 16.5 gestation days fetal cerebral cortices of rats for the direct examination of the role of molecules that are known to regulate the integrin-mediated cell migration. Because different ECM molecules are secreted by radial glial cells during development $[27,28]$, initially different concentrations of laminin and fibronectin were examined on the migration of fetal cortical neurons. The propensity of $\alpha$ subunits forming integrin receptor/s with the $\beta 1$ subunit to support migration was examined by using the same concentration of antibodies against different $\alpha$ subunits at which the migration of neurons was significantly inhibited by antibody against $\beta 1$ subunit. Roles of different intracellular molecules (src kinase, phospholipase C, calcium, protein kinase C, MEK kinase, and microtubules) that are known to support integrin-mediated migration of different cell types [29-31] were examined on neuron migration by using pharmacological inhibitors or intracellular calcium chelator. The roles of $\beta 1$ and $\alpha 3$ integrin subunits, the intracellular molecules, and the calcium chelator were also examined on neuritogenesis.

\section{Materials and Methods}

2.1. Animals and Compliance. Time pregnant Long-Evans rats were obtained from Charles River (Boston, MA). Animals were housed in the animal facility of the University of Mississippi Medical Center on chow and water ad libitum and used for studies according to a protocol approved by the Institutional Animal Care and Use Committee of the University of Mississippi Medical Center.

2.2. Reagents. Hanks' balanced salt solution (HBSS), Dulbecco's modified eagles medium and F12 medium (DF), B27, Trypsin inhibitor, mouse laminin, bovine fibronectin, nuclear stain Hoechst 33342, magnesium sulphate, Trypsin, and cell culture tested Dimethyl sulfoxide were purchased from Sigma-Aldrich Chemical Company, St. Louis, MO. Molecular weight markers used in western blot studies were obtained from Bio-Rad Laboratories (Hercules, CA).
Monoclonal antibodies against the extracellular domains of integrin subunits were obtained from different commercial sources in no-azide formulations or freed from sodiumazide using Nanosep centrifugal devices (PALL Life Sciences, Ann Arbor, MI). Additional information on these antibodies as well as those used in the immunofluorescent staining and western blotting experiments (see below) is provided in Table 1. Inhibitors against different enzymes that are known to regulate integrin signaling in different cell types and modulators of intracellular calcium levels are mentioned in Table 2.

2.3. Preparation of Dissociated Neurons. Dissociated neurons were prepared from cortices as described previously [39] with some modifications. Briefly, on gestation days 16.5, pregnant rats were deeply anesthetized with isoflurane, fetuses were removed from uteri, and cerebral cortices of fetal brains were dissected out as described previously [40]. Cerebral cortices were incubated in HBSS containing 0.1\% Trypsin for $15 \mathrm{~min}$ at $37^{\circ} \mathrm{C}$. Cortices were triturated in HBSS containing $0.025 \%$ DNase I, 0.2\% Trypsin inhibitor, 0.2\% BSA, and $12 \mathrm{mM} \mathrm{MgSO}_{4}$ and centrifuged at $160 \mathrm{~g}$. The resulting pellet was suspended in HBSS and centrifuged. Supernatant was discarded and the pellet was suspended in the culture medium DMEM/F-12 (1:1) containing 0.2\% B-27 to estimate the number using a hemacytometer (Hausser Scientific, Horsham, PA). The neurons were used for migration assays and also cultured on laminin-coated wells of 8 chambered glass slides (Thermo Fisher Scientific, Houston, TX) for immunofluorescent microscopy and neuritogenesis assays or in flasks (Fisher Scientific) for western blotting and RNA isolation.

2.4. In Vitro Neuron Migration Assay. The Boyden Chamber assay that has been successfully used for estimating the migration of fetal brain neurons previously by different laboratories $[39,41-43]$ was used for this study. Specifically, the Boyden chamber assay for studying fetal cerebral cortical neurons of Maeda and Noda (1998) [39] was used with some modifications. Transwell inserts (diameter $6.5 \mathrm{~mm}$ ), each consisting of polycarbonate membranes with $3.0 \mu \mathrm{m}$ pore size with pore density $2 \times 10^{6} / \mathrm{cm}^{2}$ (Fisher Scientific; Pittsburgh, PA) were used for migration assays. Undersurface of membranes of Transwell inserts was first coated with Poly D Lysine $(10 \mu \mathrm{g} / \mathrm{mL})$ overnight and then with solution $(100 \mu \mathrm{L})$ of laminin, fibronectin, or only water (diluent of laminin or fibronectin solutions) and dried overnight in sterile conditions prior to use. In all migration assays, the lower chamber contained $500 \mu \mathrm{L}$ of culture medium (controls) or medium containing antibody against integrin subunit, inhibitor, or calcium chelator (see below) and the upper chamber contained $200 \mu \mathrm{L}$ of medium containing 150,000 dissociated neurons. Plates containing the Boyden chamber assemblies were incubated for $18 \mathrm{~h}$ in an incubator $\left(37^{\circ} \mathrm{C}, 5 \% \mathrm{CO}_{2}\right.$, humidity $\left.99 \%\right)$. At the end of incubation, membranes were treated with chilled $4 \%$ paraformaldehyde solution for $20 \mathrm{~min}$ and the neurons on the upper surface of the membranes were removed by rubbing with cotton 
TABle 1: Antibodies, commercial sources, and applications.

\begin{tabular}{|c|c|c|}
\hline Antibody & Source & Experiments \\
\hline $\begin{array}{l}\text { Monoclonal antibodies against } \beta 1 \text { integrin subunit } \\
(\text { Clone } \mathrm{Ha} 2 / 5)\end{array}$ & BD Biosciences (San Jose, CA) & Migration assays \\
\hline $\begin{array}{l}\text { Monoclonal antibodies against } \beta 3 \text { integrin subunit } \\
\text { (Clone 25E11) }\end{array}$ & Chemicon International (Temecula, CA) & Migration assays \\
\hline $\begin{array}{l}\text { Monoclonal antibodies against } \alpha 3 \text { integrin subunit } \\
\text { (Clone P1B5) }\end{array}$ & Chemicon International & Migration assays \\
\hline $\begin{array}{l}\text { Monoclonal antibodies against } \alpha 4 \text { integrin subunit } \\
\text { (Clone } \mathrm{R} 1-2)\end{array}$ & BD Biosciences & Migration assays \\
\hline $\begin{array}{l}\text { Monoclonal antibodies against } \alpha 5 \text { integrin subunit } \\
\text { (Clone VC5) }\end{array}$ & BD Biosciences & Migration assays \\
\hline $\begin{array}{l}\text { Monoclonal antibodies against } \alpha v \text { integrin subunit } \\
\text { (Clone H9.2B8) }\end{array}$ & BD Biosciences & Migration assays \\
\hline $\begin{array}{l}\text { Monoclonal antibodies against } \alpha 6 \text { integrin subunit } \\
\text { (Clone NKI-GoH3) }\end{array}$ & BD Biosciences & Migration assays \\
\hline Control IgG (Clone A19-4) & BD Biosciences & Migration assays \\
\hline Control IgM (Clone G235-1) & BD Biosciences & Migration assays \\
\hline $\begin{array}{l}\text { Monoclonal antibody against NeuN } \\
\text { (Clone A60) }\end{array}$ & Chemicon International & Immunofluorescent microscopy \\
\hline Rabbit Polyclonal antibody against MAP2 (AB5622) & Chemicon International & Immunofluorescent microscopy \\
\hline Monoclonal Antibody against microtubules (E7) & Hybridoma Bank (University of Iowa, IA) & Immunofluorescent microscopy \\
\hline Monoclonal antibody against $\beta$-Actin (Clone C4) & BD Biosciences & Western blotting \\
\hline $\begin{array}{l}\text { Purified mouse anti (pTyr783)-Phospolipase C } \gamma 1 \\
\text { Clone 27/Phospholipase C- } \gamma \text { (pY783) }\end{array}$ & BD Biosciences & Western blotting \\
\hline $\begin{array}{l}\text { Alexa Fluor 594-conjugated secondary antibodies } \\
\text { (Donkey anti-mouse or rabbit) }\end{array}$ & Invitrogen, Carlsbad, CA & Immunofluorescence microscopy \\
\hline $\begin{array}{l}\text { Peroxidase-conjugated secondary antibodies } \\
\text { (Donkey anti-mouse) }\end{array}$ & Jackson Immuno-research, West Grove, PA & Western blotting \\
\hline
\end{tabular}

TABLE 2: Inhibitors, intracellular calcium regulators and targets.

\begin{tabular}{|c|c|c|}
\hline Inhibitor & Target & Concentration/references \\
\hline $\begin{array}{l}\text { 4-Amino-5-(4-chlorophenyl)-7-(t-butyl) parasol [3,4-] } \\
\text { pyrimidine (PP2) and control compound (PP3) }\end{array}$ & Src family of tyrosine kinases & $20 \mu \mathrm{M}[32]$ \\
\hline $\begin{array}{l}\text { 1-[6-((17 } \beta \text {-3-Methoxyestra-1,3,5(10)-trien-17-y) amino) } \\
\text { hexyl]-1H-pyrrole-2,5-dione (U-73122 or U2) and control } \\
\text { compound U-73343 or U3 }\end{array}$ & Phospholipase $\mathrm{C}$ activation & $10 \mu \mathrm{M}[33]$ \\
\hline $\begin{array}{l}\text { 2'Amino-3'-Methoxyflavone } \\
\text { (PD98059 or PD) }\end{array}$ & MAP kinase kinase & $20 \mu \mathrm{M}[34]$ \\
\hline $\begin{array}{l}\text { 2-(Aminoethoxy) diphenylborate } \\
\text { (2-APB) }\end{array}$ & Ins $(1,4,5) \mathrm{P}_{3}$-induced $\mathrm{Ca}^{2}$ release & 40 and $100 \mu \mathrm{M}$ [35] \\
\hline $\begin{array}{l}\text { 1,2-bis(o-Aminophenoxy) ethane-N,N,N', } \mathrm{N}^{\prime} \text {-tetraacetic acid } \\
\text { tetra (BAPTA/AM) }\end{array}$ & Calcium chelator & 2.5 and $10 \mu \mathrm{M}[36]$ \\
\hline Calphostin C (UCN-1028c) & Protein kinase C & $50 \mathrm{nM}[37]$ \\
\hline Ammoniated Ruthenium Oxychloride (RR) & $\begin{array}{l}\text { Calcium-induced calcium release from } \\
\text { Ryanodine-sensitive intracellular calcium } \\
\text { stores }\end{array}$ & $50 \mu \mathrm{M}[38]$ \\
\hline
\end{tabular}

swabs twice. Preliminary experiments were conducted to ensure that rubbing technique removes all neurons from the upper surface of membrane and the incubation time that provided adequate number of neurons for migration assays. Membranes were cut and processed for the immunofluorescent detection of neuronal nuclei and neuronal marker
MAP2 expression as described below (see Section 2.10). All migration assays were performed at least three times with two Boyden chamber assemblies per experimental conditions. Images of different fields vertically and across (total 9) of each membrane were captured at 10x magnification. Total numbers of nuclei from each image of controls and 
experimental groups were counted using the counting tool of the Metamorph software to determine the number of nuclei per membrane for analysis.

2.5. ECM Effects on the Migration of Neurons. Relative roles of ECM proteins (laminin and fibronectin) on the migration of dissociated neurons were examined by coating Poly-D lysine treated membranes with different concentrations of laminin $(1,5,10,20$, and $50 \mu \mathrm{g} / \mathrm{mL})$ or fibronectin $(10,20$, 50,100 , and $200 \mu \mathrm{g} / \mathrm{mL}$ ) in sterile water. Medium containing neurons $(150,000)$ were added in the upper chamber and the lower chambers contained medium only. Chambers were incubated for $18 \mathrm{~h}$ and the neurons on the undersurface of the membranes were counted as described above.

2.6. Antibody Effects on the Migration of Neurons. Relative roles of different integrin $\alpha$ subunits with respect to $\beta 1$ subunit on the migration of neurons were examined using functional blocking antibodies. Azide-free monoclonal antibody against different integrin subunits, control IgG, or IgM were added in the medium of lower chamber. Control chambers contained only medium in both upper and lower chambers. Upper chamber contained neurons $(150,000)$ in the medium $(200 \mu \mathrm{L})$. Neurons on the lower surface of membranes were counted at the end of $18 \mathrm{~h}$ incubations as described above. Initial experiments were conducted with monoclonal antibodies against $\beta 1$ integrin subunit to determine the concentration ( $50 \mathrm{nMole}$ ) that significantly inhibited the migration of neurons at $P<0.05$ on laminin $(10 \mu \mathrm{g} / \mathrm{mL})$. Relative effects of monoclonal antibodies against additional integrin subunits at ( $50 \mathrm{nMole})$ were tested on the migration of neurons on laminin $(10 \mu \mathrm{g} / \mathrm{mL})$ or fibronectin $(100 \mu \mathrm{g} / \mathrm{mL})$ coated membranes. These antibodies (see Table 1) are tested for their efficacy by the supplier and also reported for their interaction with integrin subunits on cell surface and inhibition of cell adhesion [44-50].

2.7. Effects of Inhibitors or Calcium Chelator on the Migration of Neurons. Involvements of different intracellular signaling molecules in the migration of neurons were examined using pharmacological inhibitors. This included inhibitors PP2, U-73122 (U2), PD98059 (PD), Calphostin C, 2-APB, and Ruthenium Red against Src family of tyrosine kinases, PLC activation, MAP kinase kinase, Protein kinase C, IP3induced calcium release, and calcium induced calcium release from Ryanodine receptors, respectively. Role of intracellular calcium on migration was examined using the chelator BAPTA-AM. Inhibitors (PP2, U2, 2-APB, and PD) or control compounds U-73343 (U3) and PP3 and intracellular calcium regulators (BAPTA-AM and Ruthenium Red) were added in the medium of lower chamber. Upper chamber contained 150,000 neurons suspended in the medium only. The concentrations of these pharmacological compounds, their target and relevant references, are mentioned in Table 2 .

2.8. Effects of Antibodies, Inhibitors, or Calcium Chelator on Neuritogenesis. Roles of integrin subunits, intracellular signaling molecules and calcium on neuritogenesis were examined using antibodies, pharmacological inhibitors, and calcium chelators. Wells of 8 chambered glass slides were coated with gelatin $\left(12 \mathrm{~h}\right.$ at $\left.4^{\circ} \mathrm{C}\right)$ followed by laminin $(10 \mu \mathrm{g} / \mathrm{mL})\left(12 \mathrm{~h}\right.$ at $\left.4^{\circ} \mathrm{C}\right)$. Dissociated neurons $(100,000)$ were cultured in wells in the absence (control) or presence of monoclonal antibody (Table 1), inhibitor, or calcium modulators (Table 2 ) for $20 \mathrm{~h}$ and bright-field images (6/well $=3$ vertical and 3 across) of neurons were captured. High contrast images were captured for visualization and tracing of neurites with the tools of Metamorph software. Experiments were repeated to collect data from at least 3 wells per control and treatment conditions (18 images/treatment condition).

2.9. Effects of BAPTA on the Expression of Microtubules. Role of intracellular calcium on the expression of microtubules was examined using different concentrations of calcium chelator BAPTA-AM $(0,5,10$, and $20 \mu \mathrm{M})$ by immunofluorescent microscopy (see below).

2.10. Immunofluorescent Microscopy. Expression of neuron markers (NeuN and MAP2) and microtubules were examined in the dissociated neurons by immunofluorescent microscopy. Briefly, at the completion of paraformaldehyde treatments, neurons on the undersurface of membranes or in the wells of eight chambered slides were treated with Triton $(0.1 \%)$ for $10 \mathrm{~min}$ and rinsed with PBS prior to incubating with the primary antibody solution in Phosphate Buffer Saline (PBS) containing Bovine Serum Albumin (BSA) $(1 \mathrm{mg} / \mathrm{mL})$ overnight at $4^{\circ} \mathrm{C}$. Dilution of primary antibodies for the detection of NeuN, Microtubules, and MAP2 in PBSBSA solutions were $1: 10,1: 200$, and $1: 1000$, respectively. Membranes or wells were rinsed with PBS three times (15 min each) and then incubated with Alexa dye conjugated secondary antibody $(10 \mu \mathrm{g} / \mathrm{mL})$ and nuclear stain Hoechst 33342 (dilution 1:200). Fluorescent images were captured using a Nikon Eclipse (TE-2000 U) Microscope.

\subsection{Reverse Transcription and Polymerase Chain Reactions} (RT-PCR). Expression of transcripts representing different integrin subunits in the fetal cortical neurons, cultured on laminin-coated flasks for $7 \mathrm{~h}$, was examined using RT-PCR in three occasions. In each experiment, the total RNA $(1 \mu \mathrm{g})$ isolated from the neurons using Trizol-reagent (Invitrogen, Carlsbad, CA) was subjected to complementary DNA (cDNA) synthesis using a Reverse transcription III kit (Invitrogen). Equal amounts (50 ng equivalent) of cDNA samples were amplified by PCR. The primer sequences (Table 3) were either obtained from the literature [51-53] or subjecting the rat or homologous regions of mice and human cDNA sequences (GenBank) to Primer3 software (http://flypush.imgen.bcm.tmc.edu/primer/primer3_ www.cgi/). Authenticity of these primers was tested by PCR using cDNA from rat and human cell lines (rat PC12 and cardiac myoblasts; human trophoblast and colon cancer cell lines) that produced expected size amplicons with no spurious bands. Identity of amplicons representing $\alpha 3$ and $\alpha 9$ 
TAble 3: Primers used for the amplification of integrin cDNA from rat fetal brain neurons.

\begin{tabular}{lccc}
\hline Subunit & Sense primer $\left(5^{\prime}-3^{\prime}\right)$ & Antisense primer $\left(5^{\prime}-3^{\prime}\right)$ & Amplicon size \\
\hline$\beta 1$ & aatgtttcagtgcagagcc & ttgggatgatgtcgggac & 261 \\
$\beta 3$ & agctgtcgctgtccttcaat & cctgctgagagggtcgatag & 357 \\
$\beta 4$ & gctctacacggacaccacct & tgcagcaggcacagtatttc & 398 \\
$\alpha 1$ & tggatattggccctaagcag & cgcttgcgatcgattttatt & 399 \\
$\alpha 2$ & tggggtgcaaacagacaagg & gtaggtctgctggttcagc & 539 \\
$\alpha 3$ & ctgctgccaaaaaagccaagt & ggcagctcctccaccagct & 300 \\
$\alpha 4$ & cccaggctacatcgtttgt & atggtcttcatgctcccaac & 444 \\
$\alpha 5$ & aggtgacgggactcaacaac & agccgagcttgtagaggaca & 489 \\
$\alpha v$ & gagcagcaaggactttggg & gggtacacttcaaggccagc & 619 \\
$\alpha 6$ & gactcttaactgtagcgtga & atctctcgctcttctttccg & $550(\alpha 6 \mathrm{~A}), 420(\alpha 6 \mathrm{~B})$ \\
$\alpha 9$ & tcccccagtactcgatgaag & cagtctctcccagcaacaca & 396 \\
\hline
\end{tabular}

integrin subunit was confirmed by commercial sequencing (Retrogen, Inc., SanDiego, CA).

2.12. Western Blotting. A previously described western blotting methodology [40] was used to examine the expressions of phosphorylated PLC- $\gamma 1$ in the dissociated neuronal preparations cultured on laminin-coated flasks for $6 \mathrm{~h}$. Clear lysatefrom neurons containing $10 \mu \mathrm{g}$ proteins were denatured by boiling in the presence of lane marker buffer (Pierce) and subjected to electrophoresis on a 7.5\% Polyacrylamide gel containing sodium dodecyl sulphate. Molecular weight markers (Bio-Rad) were also loaded in adjacent lanes. At the end of electrophoresis separated proteins were transferred on to nitrocellulose membranes and probed with primary antibodies against phosphorylated PLC- $\gamma 1$ and $\beta$ Actin (Table 1). Membranes were washed and exposed with Peroxidase conjugated secondary antibodies. Bands were detected using Amersham Hyper film ECL (GE Healthcare Ltd., Buckinghamshire, UK). The experiment for the detection of phosphorylated PLC- $\gamma$ was tested using 3 different neuron preparations.

2.13. Statistical Analysis. Analysis of the neuronal migrations and neuritogenesis was conducted by ANOVA using SPSS software (SPSS, Chicago, IL). Neuron migrations were assayed by comparing the mean \pm standard errors of mean values of the number of neuronal nuclei from 9 fields under each Boyden membrane of total 6 to 9 membranes per treatment group. The neuritogenesis was examined by comparing the mean \pm standard errors of mean values of the neurite lengths from 6 fields per well (total 3 wells of each control and treated groups). Differences in Mean \pm Standard errors of mean values at $P<0.05$ were considered significant.

\section{Results}

3.1. Isolation of Fetal Cortical Neurons. The number of neurons isolated per pair of cortices by the described method was approximately $5 \times 10^{7}$ neurons $(N=7)$. These neurons attached with the laminin-coated wells and majority (approximately 95\%) expressed neuronal marker NeuN
(Figure 1), and when incubated in Boyden chambers for $18 \mathrm{~h}$, migrated at the undersurface of the membranes and expressed neuronal marker MAP2 (Figure 2).

3.2. ECM Effects on the Migration of Neurons (Figure 3). Migration of cortical neurons was higher on membranes coated with $5,10,20$, or $50 \mu \mathrm{g} / \mathrm{mL}$ laminin than those coated with only $1 \mu \mathrm{g} / \mathrm{mL}$ laminin or no laminin. Highest migration of neurons occurred on membranes coated with $10 \mu \mathrm{g} / \mathrm{mL}$ laminin. The migration of neurons on membranes coated with $20,50,100$, or $200 \mu \mathrm{g} / \mathrm{mL}$ fibronectin was higher than those coated with $10 \mu \mathrm{g} / \mathrm{mL}$ fibronectin or no fibronectin. The migration of neurons on membrane coated with 100 or $200 \mu \mathrm{g} / \mathrm{mL}$ fibronectin was not significantly different $(P>0.05)$. Further studies on the migration of neurons were conducted with membranes coated with Poly-D lysine followed by $10 \mu \mathrm{g} / \mathrm{mL}$ laminin or $100 \mu \mathrm{g} / \mathrm{mL}$ fibronectin (see below).

3.3. Antibody Effects on the Migration of Neurons (Figure 4). Antibody against $\beta 1$ or $\alpha 3$ integrin subunit significantly decreased migration of neurons on laminin-coated membranes $(P<0.05)$. Antibody against $\alpha 6$ subunit did not alter the migration of neurons on laminin-coated membranes. Moreover, the migration of neurons was not altered by control antibody (IgG or IgM) or the antibody against the $\alpha v$ subunit (negative control on laminin) on laminin-coated membranes. On fibronectin-coated membranes, only antibody against $\beta 1$ subunit inhibited the migration $(P<0.05)$. The migration of neurons on fibronectin-coated membranes was not altered by control antibodies (IgG or $\operatorname{IgM}$ ), and antibodies against $\beta 3$ (negative control since not expressed), $\alpha 4, \alpha 5$, or $\alpha v$ subunits.

3.4. Effects of Inhibitors and Calcium Modulators on the Migration of Neurons (Figure 5). PP2 (the inhibitors of Src kinase activation), U2 (the inhibitor of PLC $\gamma$ activation), and the light-activated Calphostin (the inhibitor of PKC activation) inhibited the migration of neurons on both laminin- and fibronectin-coated membranes $(P<0.05)$. Migrations of neurons were not significantly altered in the presence of MAP 


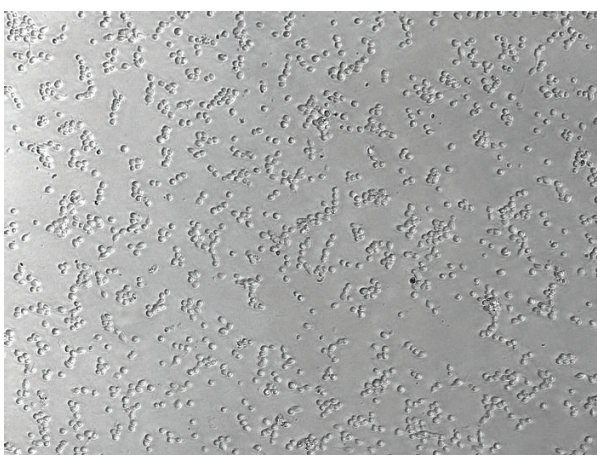

(a)

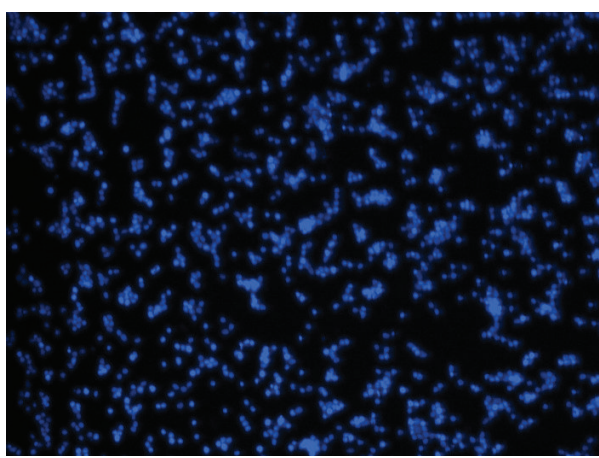

(c)

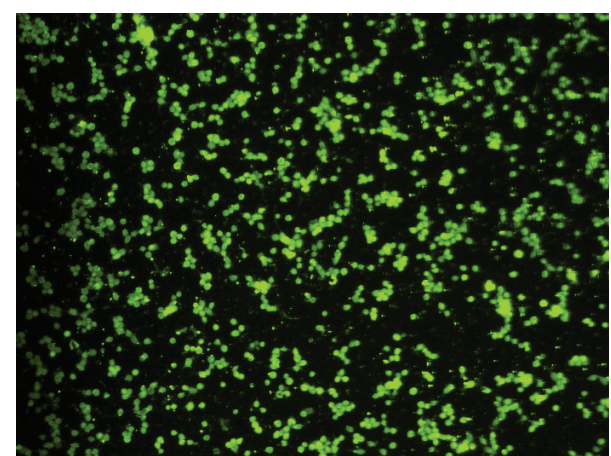

(b)

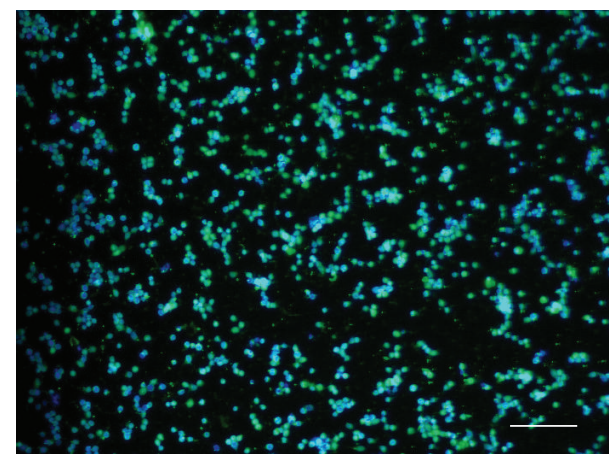

(d)

FIGURE 1: Dissociated neurons in culture. Dissociated neurons at $2 \mathrm{~h}$ of plating on laminin-coated plates (a) immunostained for the neuronal marker NeuN (b) and nuclear stain Hoechst (c). Image (d) shows the overlaps of images (b) and (c). Bar100 microns. Note, Hoechst stained nuclei are out of focus because all images are captured at the same plane as (a).

Kinase Kinase (MAPK/ERK kinase or MEK) inhibitor PD, control compounds U3 or PP3 on laminin, or fibronectincoated membranes $(P>0.05)$. The inhibitor of IP3 receptorinduced calcium release from intracellular stores (2-APB) and the intracellular calcium chelator BAPTA-AM inhibited the migration both on laminin- and fibronectin-coated membranes. Ruthenium Red, the inhibitor of intracellular calcium-induced calcium release from Ryanodine receptor containing calcium stores, did not alter the migration of neurons.

3.5. Effects of Antibodies, Inhibitors, and Calcium Modulators on Neuritogenesis. Antibodies against $\beta 1$ or $\alpha 3$ subunit inhibited neuritogenesis of fetal cortical neurons. Neuritogenesis was not inhibited in the presence of control antibodies (IgG) at $50 \mathrm{nM}$ (Figure 6(a)) and even at higher concentration (100 nM), (Figure 6(b)). BAPTA-AM completely abolished the neurite formation at higher concentration $(10 \mu \mathrm{M})$, (Figure 6(a)). The inhibitors of Src kinase (PP2), PLC- $\gamma$ respectively (U2), IP-3 induced calcium release (2-APB), Protein kinase $\mathrm{C}$ (activated calphostin), MAP kinase kinase (PD), and the calcium chelator (BAPTA-AM) significantly reduced the neurite lengths (Figure 6(c)). Neuritogenesis was not inhibited in the presence of control compounds of pharmacological inhibitors (PP3 and U3) or the inhibitor of Ryanodine receptor mediated release of intracellular calcium
(Ruthenium Red) (Figure 6(c)). BAPTA-AM decreased the expression of microtubules in cortical neurons (Figure 7).

3.6. Expression of Phosphorylated PLC 1 and Integrin Subunit mRNA Species in Dissociated Neurons. Western blotting experiments with lysate prepared from neurons at $6 \mathrm{~h}$ of culture provided evidence for the presence of PLC- $\gamma 1$ in its phosphorylated state at tyrosine 783 (Figure 8). Neurons at $6 \mathrm{~h}$ of culture expressed mRNA for $\beta 1, \alpha 1, \alpha 3, \alpha 4, \alpha 5, \alpha v$, and $\alpha 9$ integrin subunits (Figure 9).

\section{Discussion}

Cortical neurons isolated from rat fetal (GD16.5) brains expressed subunits for integrin receptors and responded to cues of both laminin and fibronectin during their migration in vitro. These neurons utilized the intracellular signaling molecules and cytoskeletal elements that are known to transmit integrin receptor signaling during cell migration and differentiation. At the same concentrations, the effects of inhibitors and intracellular calcium modulators were more robust on neuritogenesis than on migration. Results showed that growth factor signaling via MEK is only required for neuritogenesis. The connotations of these findings are discussed below. 


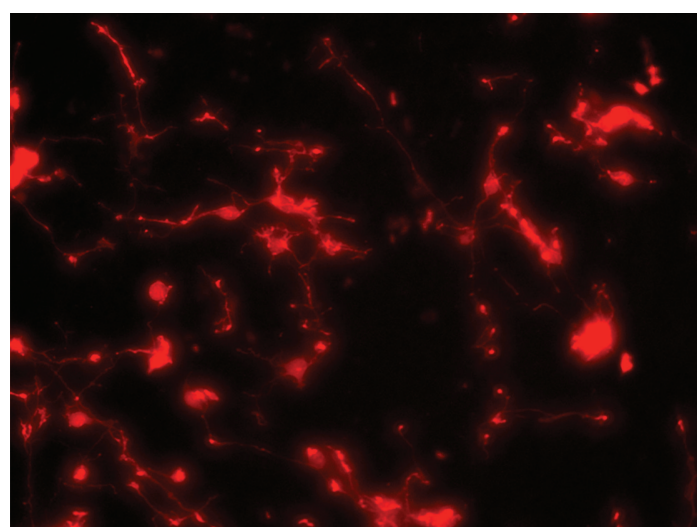

(a)

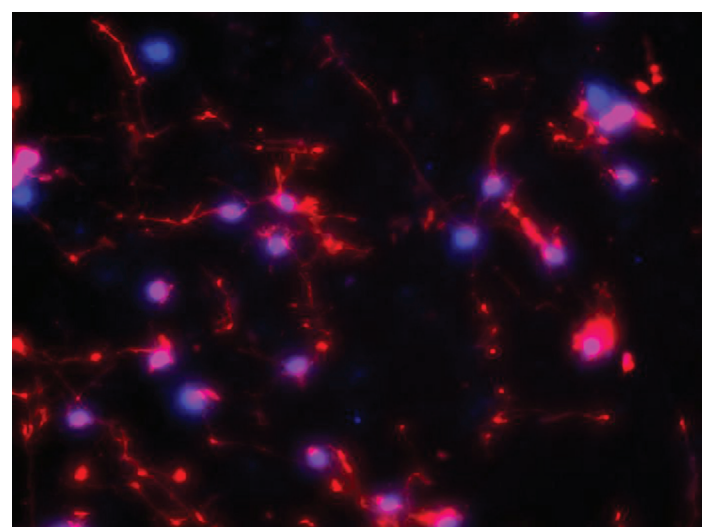

(b)

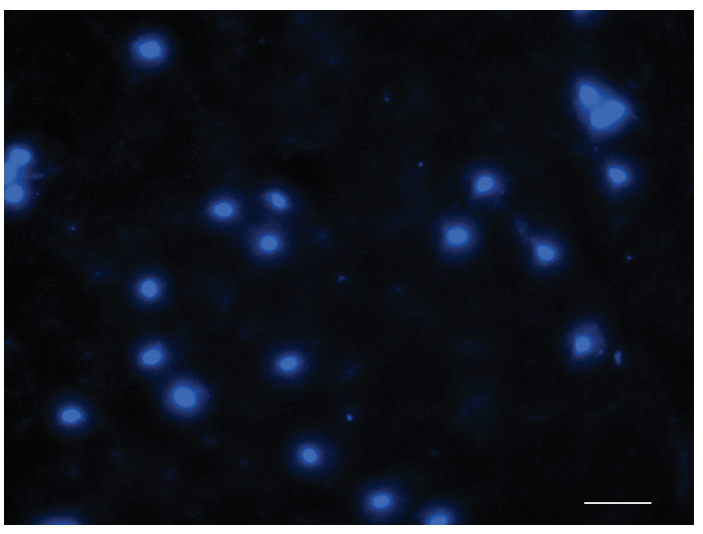

(c)

FIGURE 2: Neurons at the undersurface of membrane. Neurons migrated at the undersurface of membrane expressed neuronal marker MAP2 (a). Neuronal nuclei stained with Hoechst (c). Overlapping images (a) and (c) are shown in (b). Bar 100 microns.

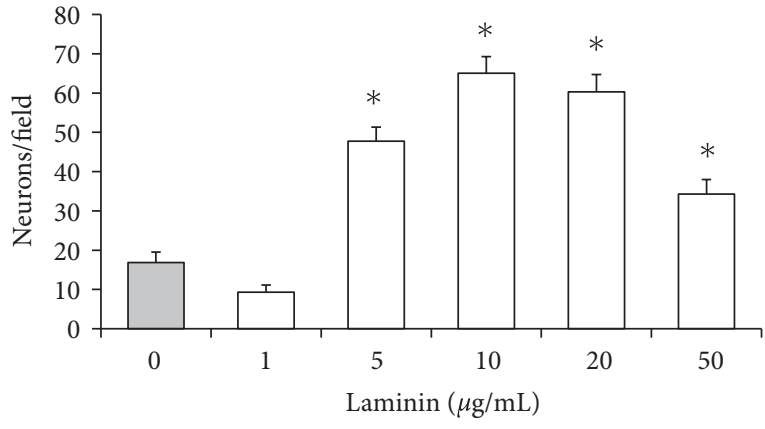

(a)

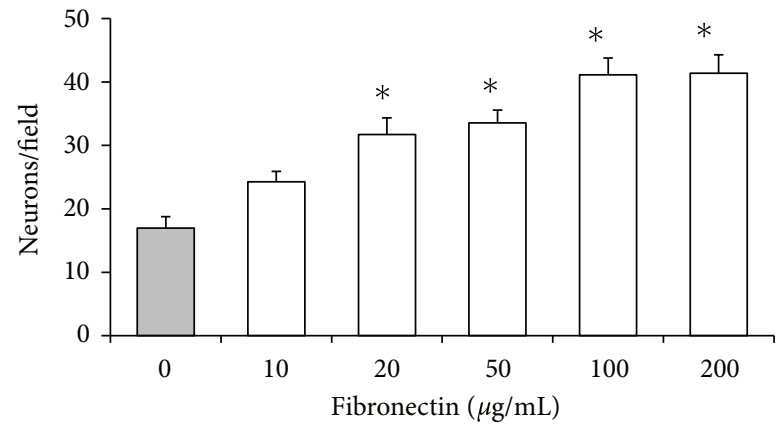

(b)

FiguRE 3: ECM effects on the migration of neurons. Neurons per field of Boyden membrane coated with laminin (a) or fibronectin (b). ${ }^{*}$ Migration of cortical neurons were significantly $(P<0.05)$ higher on membranes coated with laminin at $5,10,20$, and $50 \mu \mathrm{M}$ or 20 to $200 \mu \mathrm{M}$ fibronectin compared to those coated with only Poly-D lysine (shaded bar). Migration of neurons was highest at $10 \mu \mathrm{M}$ laminin but it was not significantly different than those at $20 \mu \mathrm{M}$ laminin. Migration of neurons on fibronectin-coated membranes increased with concentration to reach its maximum at $100 \mu \mathrm{M}$ that was not significantly $(P>0.05)$ different than membranes coated with $200 \mu \mathrm{M}$ fibronectin.

Membranes coated with laminin or fibronectin enhanced the migration of fetal cortical neurons (Figure 3). It was evident that laminin at a 10-fold lower concentration supported the migration better than fibronectin suggesting that laminin may be a better substrate for the migration of fetal brain neurons. This observation is consistent with the migration pattern of neuronal precursors derived from embryonic stem cells [14]. Optimum adhesion with the ECM is critical for the normal migration of cells $[54,55]$. Therefore, the enhanced migration of neurons with the increased concentration of 


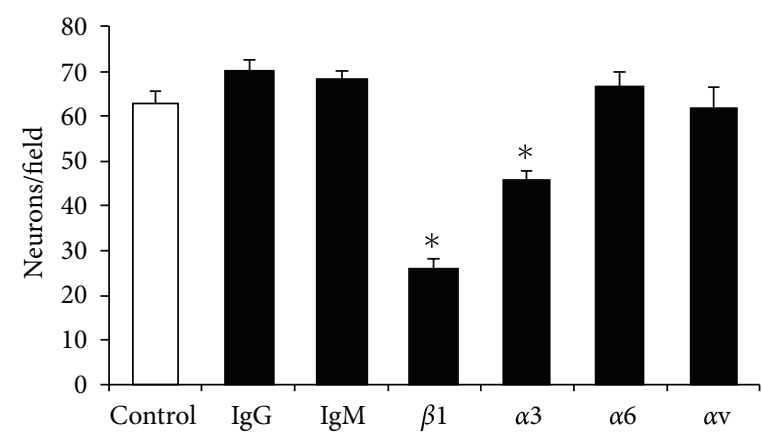

(a)

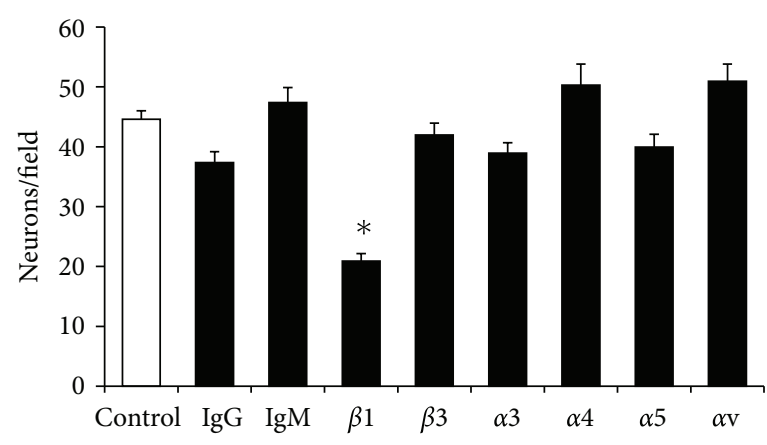

(b)

FIGURE 4: Effects of antibodies on the migration of fetal cortical neurons. Monoclonal antibodies (shown below) against $\beta 1$ and $\alpha 3$ integrin subunits significantly $\left({ }^{*} P<0.05\right)$ inhibited the migration of neurons (Neurons/field) on membranes coated with laminin $(10 \mu \mathrm{g} / \mathrm{mL})(\mathrm{a})$. The migrations of neurons on laminin-coated membranes were not significantly $(P>0.05)$ altered by antibody against $\alpha 6$ or $\alpha v$ subunit (the negative control) and control antibodies (IgG or IgM). The migrations of neurons on fibronectin $(100 \mu \mathrm{g} / \mathrm{mL})$ coated membranes were significantly $\left({ }^{*} P<0.05\right)$ inhibited by the antibody against $\beta 1$ integrin subunit only (b). The migrations of neurons on fibronectin-coated membranes were not altered by control antibodies (IgG or IgM) at $P>0.05$.

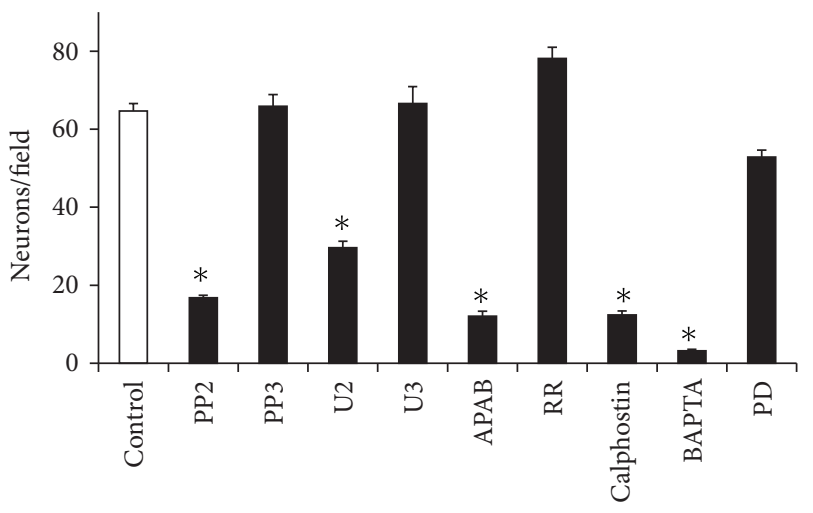

(a)

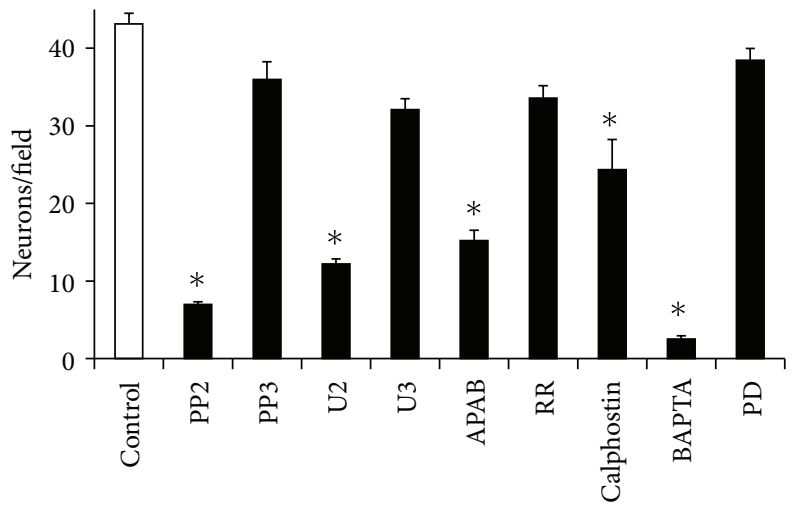

(b)

FIGURE 5: Effects of inhibitors on the migration of cortical neurons. Inhibitors (shown below) of Src kinase (PP2) and Phospholipase C $\gamma$ activity (U2) inhibited the migration of fetal cortical neurons (Neurons/field) on laminin-(a) or fibronectin-(b) coated membranes $\left({ }^{*} P<\right.$ 0.05). No significant changes in the migration of neurons occurred in the presence of control compound PP3 or U3 $(P>0.05)$. Inhibitor of protein kinase C (light-activated Calphostin), inhibitor of IP3 mediated calcium release (2-APB), and intracellular calcium chelator (BAPTA$\mathrm{AM})$ inhibited the migration of neurons significantly $\left({ }^{*} P<0.05\right)$ on laminin-(a) or fibronectin-(b) coated membranes. Ruthenium Red (inhibitor calcium-induced calcium release) and PD (inhibitor of Mitogen activated kinase kinase) did not alter the migration of neurons on laminin-(a) or fibronectin-(b) coated membranes $(P>0.05)$.

laminin and its downregulation with further increase in laminin (Figure 3(a)) indicates that the pace and the direction of neuron migration in the fetal brain may be regulated by the amount of specific ECM molecule secreted by glial cells on the migratory route.

Inhibition studies with monoclonal antibodies to examine the relative roles of different integrin subunits on migration suggested that the receptor consisting of $\alpha 3$ and $\beta 1$ subunits $(\alpha 3 \beta 1)$ primarily regulates the migration of fetal cortical neurons on laminin (Figure 4(a)). This is also in accordance with previous observations $[3,10,15]$. In addition, the lack of effects of antibody against the $\alpha 6$ integrin subunit on the $\alpha 6 \beta 1$ mediated migration is also consistent with the absence $\alpha 6$ subunit in fetal cortical neurons (Figure 9) and the lack of any direct evidence for its role in the migration of fetal cortical neurons [11]. On fibronectin-coated membranes, only the antibody against $\beta 1$ subunit inhibited the migration of neurons and antibodies against the $\alpha$ subunits $(\alpha 3, \alpha 4$, $\alpha 5$, or $\alpha v$ ) that are the constituent of fibronectin-binding receptors $(\alpha 3 \beta 1, \alpha 4 \beta 1, \alpha 5 \beta 1$, and $\alpha v \beta 1)$ did not inhibit the migration (Figure 4(b)) although the RT-PCR (Figure 9) results confirmed their expression. This finding indicates that the migration of fetal cortical neurons on fibronectin may be regulated by $\beta 1$ subunit containing integrin receptor/s other than $\alpha 3 \beta 1, \alpha 4 \beta 1, \alpha 5 \beta 1$, and $\alpha v \beta 1$. It may include the fibronectin binding receptor $\alpha 8 \beta 1$ that also interacts with ECM tenascin. The role of tenascin in the glial guided migration of fetal cortical neurons is further supported by the fact that tenascin is expressed by the radial glia in the developing brain [56] and transcripts of $\alpha 9$ subunits are 

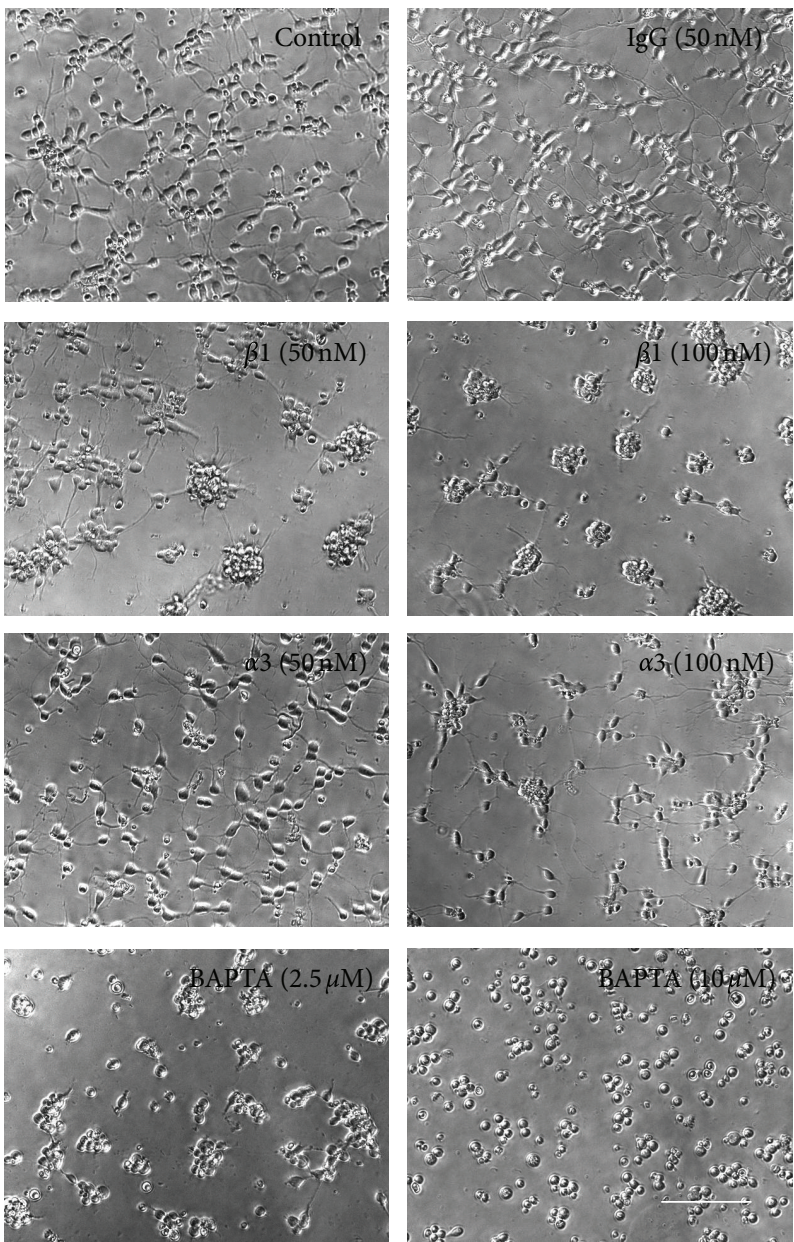

(a)

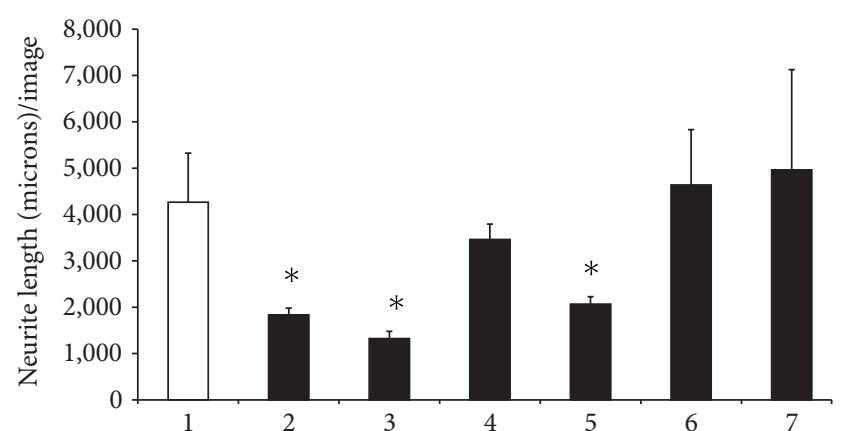

(b)

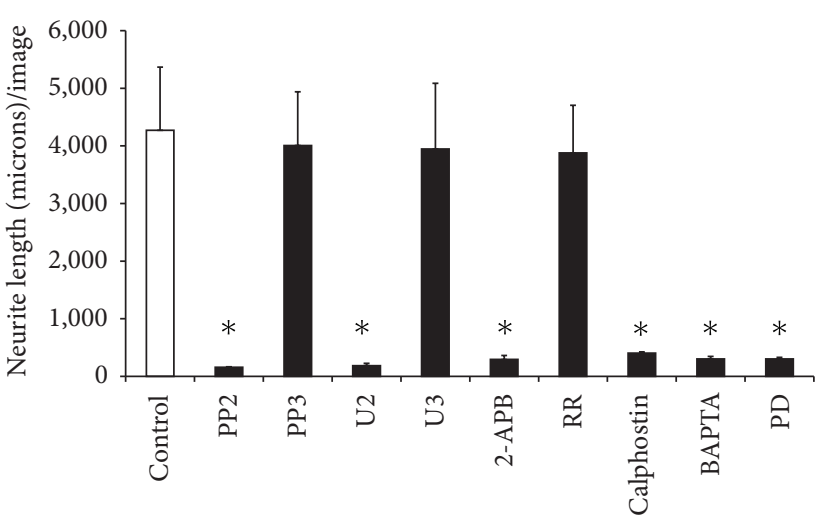

(c)

FIGURE 6: Effects of antibodies, calcium modulators, and pharmacological inhibitors on neuritogenesis. (a) Representative images showing neuritogenesis in the absence (control) or presence of control IgG ( $50 \mathrm{nMole}$ ), antibodies against $\beta 1$ ( 50 or $100 \mathrm{nMole}$ ) or $\alpha 3$ (50 or $100 \mathrm{nMole}$ ) integrin subunits on laminin. BAPTA-AM at low concentration $(2.5 \mu \mathrm{M})$ inhibited neuritogenesis and at higher concentration $(10 \mu \mathrm{M})$ totally abolished neuritogenesis. Bar150 microns. (b) Mean + standard error of mean values of neurite lengths/image in untreated neurons (1) and those treated with control IgG, monoclonal antibody against $\beta 1$ or $\alpha 3$ integrin subunit at 50 nMole or 100 nMole concentration. Neurite lengths reduced significantly $\left({ }^{*} \mathrm{P}<0.05\right)$ in neurons treated with antibody against $\beta 1$ integrin subunit at both $50 \mathrm{nMole}(2)$ and $100 \mathrm{nMole}$ (3) concentrations compared to control (1). Neurons treated with monoclonal antibody against $\alpha 3$ integrin subunit at $50 \mathrm{nMole}$ (4) were lower than the control (1) but was not statistically significant $(P>0.05)$. Neurons treated with monoclonal antibody against $\alpha 3$ integrin subunit at 100 nMole (5) significantly inhibited the neuritogenesis $\left({ }^{*} P<0.055\right)$. Neuritogenesis was not altered in presence of $50(6)$ or $100 \mathrm{nMole}(7)$ control IgG $(P>0.05)$. (c) Mean + standard error of mean values of neurite lengths/image of neurons treated with PP2, PP3, U2, U3, 2-APB, activated Calphostin, BAPTA-AM $(2.5 \mu \mathrm{M})$, and PD for $22 \mathrm{~h}$ in culture (filled bars) were significantly different $\left({ }^{*} P<0.05\right)$ from untreated neurons (blank bar) and negative controls (PP3 or U3) (filled bars). No significant changes in neurite lengths $(P>0.05)$ per image were recorded in neurons treated with $R R$. 


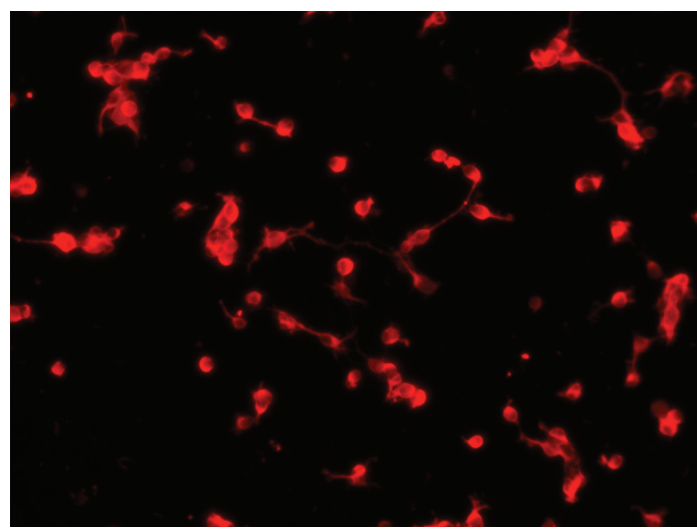

(a)

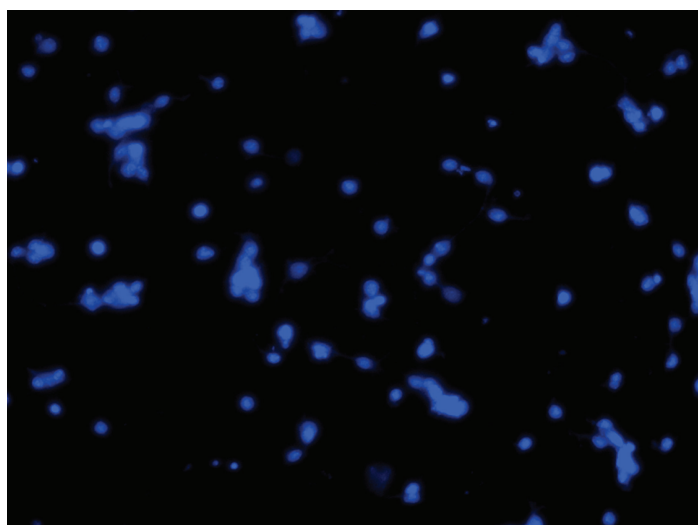

(c)

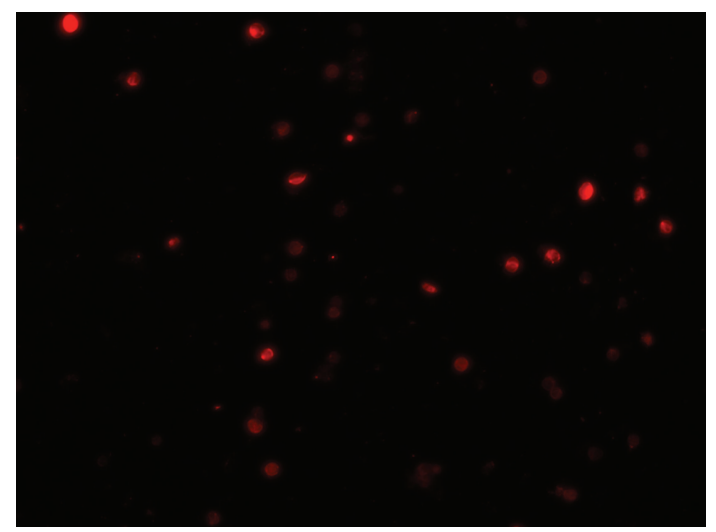

(b)

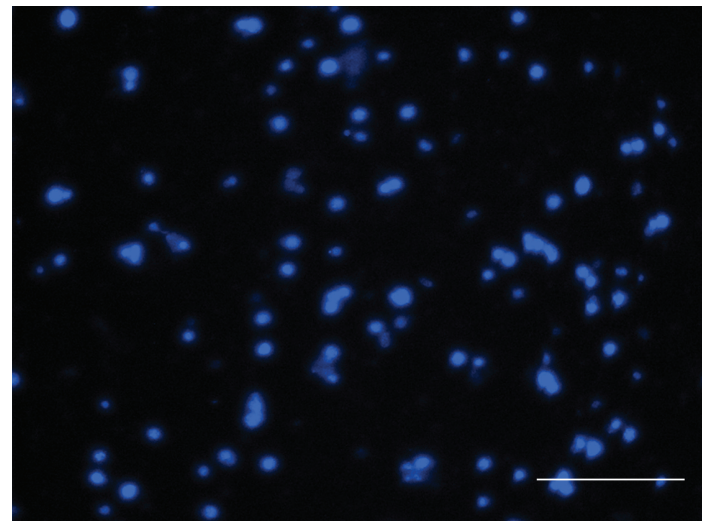

(d)

FIGURE 7: BAPTA-AM reduced microtubule expression. Microtubule expression in the untreated neurons (a) and those treated with BAPTAAM $(10 \mu \mathrm{M})(\mathrm{b})$ in culture. Panel (c) and (d) shows nuclear stain in the control and BAPTA-AM treated neurons. Bar 100 microns. Note, Hoechst stained nuclei in (c) and (d) are out of focus because images are captured at the same plane as (a) or (b), respectively. Bar 100 microns.

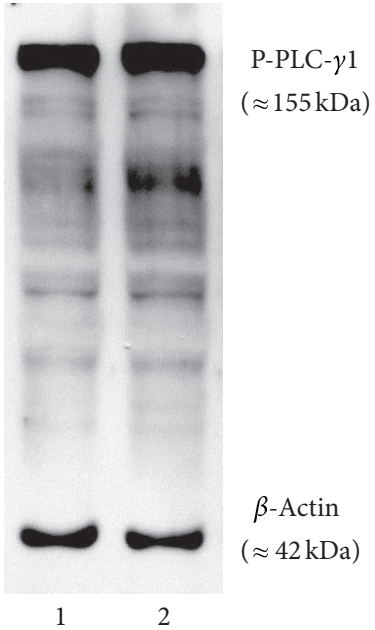

FIgURE 8: Western blotting detection of phosphorylated PLC- $\gamma 1$ in neurons. Phosphorylated form of PLC- $\gamma 1$ protein at tyrosine 783 was detected in the neurons at $6 \mathrm{~h}$ of culture on laminin simultaneously with $\beta$-actin. Lanes 1 and 2 represent lysate loaded from different neuronal preparations. Molecular weight sizes of phosphorylated form of PLC- $\gamma$ isoform and $\beta$-actin are shown in parentheses.

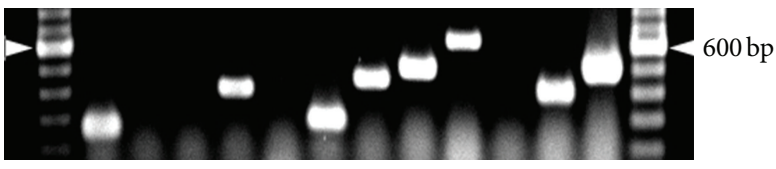

$\begin{array}{llllllllllllll}\mathrm{M} & \beta 1 & \beta 3 & \beta 4 & \alpha 1 & \alpha 2 & \alpha 3 & \alpha 4 & \alpha 5 & \alpha \mathrm{v} & \alpha 6 & \alpha 9 & 18 \mathrm{~S} & \mathrm{M}\end{array}$

FIGURE 9: Transcripts of integrin subunits in the fetal cortical neurons. Ethidium bromide stained PCR products after agarose gel electrophoresis. Target mRNA species are shown at the bottom of the image. The $600 \mathrm{bp}$ band of the $100 \mathrm{bp}$ marker $(\mathrm{M})$ is shown by arrows heads on sides.

expressed in fetal cortical neurons (Figure 9), which also forms the tenascin interacting $\alpha 9 \beta 1$ integrin receptor.

While the antibody against $\alpha v$ subunit is reported to inhibit the migration of fetal cortical neurons in an imprint assay [3], it failed to inhibit the migration on fibronectincoated membranes in the Boyden assay (Figure 4(b)). The role of integrin receptors consisting of $\alpha v$ subunits $(\alpha v \beta 1, \alpha v \beta 5$, or $\alpha v \beta 8$ ) in the migration of fetal cortical neurons is further lessened by the fact that vitronectin, the substrate for these receptors, is primarily expressed in the proximity of blood 


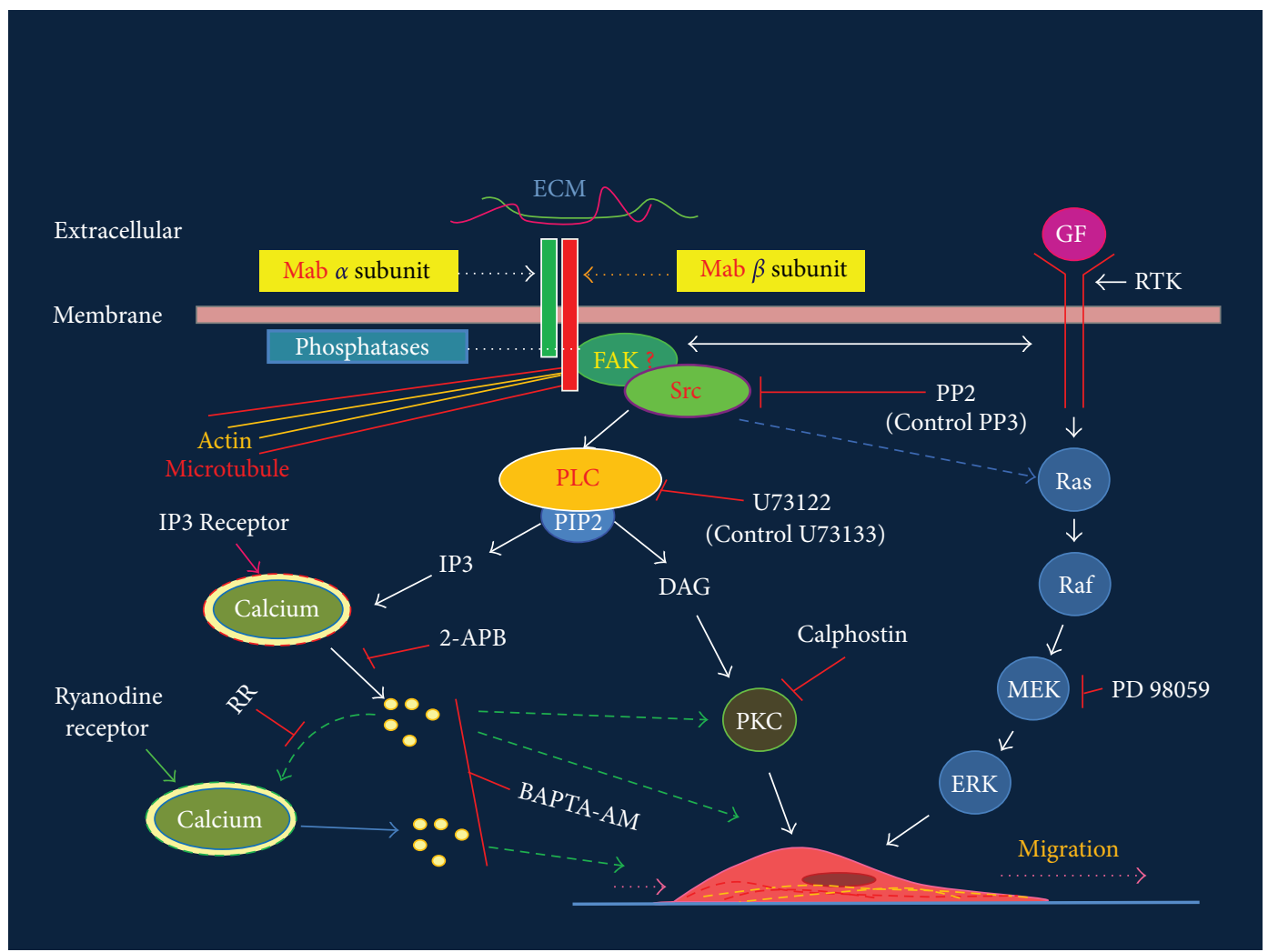

FIgURE 10: Schematic of integrin signaling cascade and its perturbation with antibodies and pharmacological agents. Integrin subunits (red and green bars on top) are shown intercalated in the membrane and interacting with ECM molecule (red and green horizontal lines). Molecules involved in signaling events are labeled and arrows point to the directions of signaling that starts with the engagement of integrin subunit with the extracellular matrix. Directions of calcium mediated signaling are shown by dashed green arrows. Inhibitors (see Table 2) used for blocking signaling molecules and paths are shown by red blocks. Cross-talk between integrin and GF signaling is shown by double headed horizontal arrow close to membrane. Mab: monoclonal antibody, GF: growth factor, RTK: receptor tyrosine kinase, MEK: MAP kinase kinase, PLC: phospholipase C, PIP2: phosphotidal inositol biphosphate, IP3: inositol (1,4,5)-triphosphate (IP3), DAG: diacylglycerol and PKC: protein kinase C, Ras: G protein, Raf: MAPKKK, MEK: MAPKK, ERK: extracellular signal regulated kinase (MAPK).

capillaries [57] and the ablation of $\alpha v$ subunit expression by gene manipulation only disturbs the development of blood vessels and axonal survival but not neuronal positioning [58]. It is surprising, however, to find no effect of antibody against $\alpha 5$ subunit on migration of neurons (Figure $4(\mathrm{~b})$ ) because its genetic manipulation at GD15.5 in mice causes laminar defects [12]. The exact reason for this discrepancy is yet to be known.

Application of different pharmacological inhibitors revealed that the intracellular molecules that mediate integrin signaling (Figure 10) and known to regulate migration of various cell types [30] are fully functional in the fetal cortical neurons. These included Src Kinase, that is activated by focal adhesion kinase following the interaction of integrin receptors with the ECM [59]; Phospholipase $\mathrm{C} \gamma$, that is activated by the activated Src Kinase, and hydrolyses membrane protein PIP2 (phosphotidal inositol biphosphate) into Inositol $(1,4,5)$-triphosphate (IP3) and Diacylglycerol (DAG) [60, 61]; Protein Kinase C, that is activated by the DAG [62], and the calcium released from the IP3 receptor containing stores [63].
The PLC- $\gamma 1$ interacts directly with the cytoplasmic tail of the $\beta 1$ integrin subunit and induces cytoskeletal organization and integrin mediated migration of cells [61]. Integrin mediated cell adhesion promotes rapid autophosphorylation [64] of Tyr-397 residue in focal adhesion kinase (FAK) promoting its interaction with the C-terminal SH2 domain of PLC- $\gamma 1$ and associating with the Src kinases at the site of integrin-ECM interactions [64]. This causes phosphorylation of Tyrosine residue 783 (Tyr783) and the activation of PLC$\gamma 1$ required for the integrin mediated upregulation of intracellular calcium and migration of cells [65]. Western blotting data (Figure 8) confirmed the presence of the activated form of PLC- $\gamma 1$ isoform in the fetal cortical neurons suggesting its possible interaction with the cytoplasmic tail of the $\beta 1$ integrin subunit in fetal cortical neurons.

Previous studies report that $\mathrm{PKC} \delta$ and atypical PKC regulate migration of neuronal precursors in the fetal cerebral cortex $[66,67]$ and different PKC isoforms (PKC $\alpha, \mathrm{PKC} \beta \mathrm{I}$, $\mathrm{PKC} \beta \mathrm{II}, \mathrm{PKC} \delta, \mathrm{PKC} \varepsilon$, and $\mathrm{PKC} \theta$ ) support migration of cells by associating with $\beta 1$ integrin subunit [68]. Robust reduction of migration in the presence of PKC inhibitor 
(Calphostin C) (Figure 5) shows that the activated state of $\mathrm{PKC}$ isoform/s in fetal cortical neurons is required for their migration on both laminin and fibronectin.

Even though the integrin and growth factor receptor cross-talk is reported to play a significant role in the migration of various cell types [31], the MEK inhibitor PD98059 did not alter the migration of fetal cortical neurons significantly (Figure 5) but rigorously reduced neuritogenesis (approximately 14 fold) (Figure $7(\mathrm{c})$ ). This suggests that the migration of fetal cortical neurons is primarily regulated by integrin mediated pathways, whereas the differentiation of these neurons is regulated by both integrin and growth factor signaling (Figure 10). The sustained expression of certain adaptor/s (such as ILK, PINCH, and Paxillin) that are required for cross-talk between integrin and growth factor receptors during differentiation but not migration of fetal cortical neurons may instruct such effects [69]. Interestingly, ILK is required for the differentiation of Bergmann glia during the cerebellar development [22].

The reduced migration of neurons in the presence of BAPTA-AM (Figure 5) confirmed previous observations that intracellular calcium is an indispensable mediator for the migration of fetal brain neurons [63]. On the other hand, no effects of high concentration $(50 \mu \mathrm{M})$ of Ruthenium Red on migration are in contrast to the finding that integrinmediated signaling mobilizes calcium from the Ryanodine Receptor gated stores [70].

The neuritogenesis data showed that the integrin receptor consisting of $\alpha 3$ and $\beta 1$ subunits also regulates neuritogenesis in rat fetal cortical neurons. This is in accordance to previous reports $[2,14]$. The present study further shows that the signaling molecules that mediate the migration of fetal cortical neurons (Src kinase, PLC- $\gamma$, Protein kinase C, IP-3 induced calcium release, and the intracellular calcium itself) also regulate the process of neuritogenesis albeit more robustly than migration (Figures 5 and 6(c)). Furthermore, inhibition of neuritogenesis by BAPTA at a moderate concentration $(2.5 \mu \mathrm{M})$, its total abolition at higher concentration $(10 \mu \mathrm{M})$ (Figure 6(a)), and reduction in microtubule expression (Figure 7) suggest that intracellular calcium not only regulates the dynamics of microtubule dynamics [71] but may also maintain its intracellular levels.

\section{Conclusions}

Rat fetal cortical neurons (isolated at GD16.5) are fully equipped with the integrin receptor and the classical intracellular signaling cascade (Figure 10) to maneuver their migration and neuritogenesis in vitro. Precisely, the lamininbinding $\alpha 3 \beta 1$ integrin receptor and intracellular signaling molecules drive both the migration and neuritogenesis while the cross-talk of integrin with growth factor signaling may add to more robust signaling towards the differentiation process. The detection of $\alpha 9$ subunit transcripts in fetal cortical neurons indicates that migration of fetal cortical neurons on radial glia may be supported by tenascin via the $\alpha 9 \beta 1$ integrin receptor. These results suggest that the composition of extracellular matrix in the path of migration and specific repertoire of integrin receptors regulates the dynamics of migration of neuronal precursors in the developing brains. The present study also indicates that calcium may regulate the migration of fetal cortical neurons also by maintaining the optimum supply of microtubules.

Additional studies are now required to delineate the exclusive role of each downstream molecule in the "outsidein" and "inside-out" integrin signaling that mediates the migration and neuritogenesis of fetal cortical neurons. This includes estimating the surface expression of each integrin subunit by flow cytometry and to examine the relevant concentrations of each antibody in the presence or absence of different combinations of pharmacological inhibitors as well as siRNA manipulation of components of integrin and growth factor signaling. Moreover, restoring the migration and neuritogenesis of neurons by activating different kinases following their inhibition by antibodies and/or pharmacological inhibitors may also be required to further ascertain their role.

Additional studies are also required to identify the PKC isoform/s that regulates the migration and neuritogenesis of fetal cortical neurons, the roles of $\alpha 1$ and $\alpha 9$ integrin subunits, that are the constituent of laminin-binding $\alpha 1 \beta 1$ and tenascin-binding $\alpha 9 \beta 1$ integrin receptors respectively, the manipulation of molecules that regulate cross-talk between integrin and growth factor signaling (such as ILK, Paxillin, and PINCH), and the Semaphorins (specifically of Semaphorin 7A) that influence axon outgrowth and activation of MAPK [72].

Finally, in the perspective of results obtained by experimenting directly with fetal cortical neurons in culture and those describing no changes in the migration of neurons in $\beta 1$ integrin mutant (in vivo studies) mice $[18,19]$, it is conceivable that the acute effects of monoclonal antibody on the neurons in culture (an in vitro test) may not be compensated which may occur in gene manipulation (in vivo) studies. It is also possible that the migration machinery of fetal cortical neurons in mice, which was used for gene manipulation studies by other investigators, may not be exactly similar to rat that was used in the current study. Even though the findings of in vitro studies presented here have their limitations, conclusions of previous gene manipulation studies [17-19] indicating that the $\beta 1$ subunit is involved in glial differentiation but not in the glial-guided migration of neurons may not be stringent as data presented here show that fetal cortical neurons do utilize $\beta 1$ and $\alpha 3$ integrin subunits and the intracellular molecules, that are known to support integrin signaling, for their migration.

\section{Conflict of Interests}

U. K. Rout has no conflict of interests pertinent to the work presented in this paper.

\section{Acknowledgments}

This study was supported by a Grant from the Center of Psychiatric Neurosciences (RR017701) and also by a Research 
Support Fund of the Department of Surgery, University of Mississippi Medical Center, Jackson, MS.

\section{References}

[1] C. Métin, J. P. Baudoin, S. Rakić, and J. G. Parnavelas, "Cell and molecular mechanisms involved in the migration of cortical interneurons," European The Journal of Neuroscience, vol. 23, no. 4, pp. 894-900, 2006.

[2] S. L. Gupton and F. B. Gertler, "Integrin signaling switches the cytoskeletal and exocytic machinery that drives neuritogenesis," Developmental Cell, vol. 18, no. 5, pp. 725-736, 2010.

[3] E. S. Anton, J. A. Kreidberg, and P. Rakic, "Distinct functions of $\alpha 3$ and $\alpha(\mathrm{v})$ integrin receptors in neuronal migration and laminar organization of the cerebral cortex," Neuron, vol. 22, no. 2, pp. 277-289, 1999.

[4] I. D. Campbell and M. J. Humphries, "Integrin structure, activation, and interactions," Cold Spring Harbor Perspectives in Biology, vol. 3, no. 3, pp. 1-14, 2011.

[5] J. Qin, O. Vinogradova, and E. F. Plow, "Integrin bidirectional signaling: a molecular view," PLoS Biology, vol. 2, no. 6, article e169, 2004.

[6] R. Milner and I. L. Campbell, "The integrin family of cell adhesion molecules has multiple functions within the CNS," Journal of Neuroscience Research, vol. 69, no. 3, pp. 286-291, 2002.

[7] M. Barczyk, S. Carracedo, and D. Gullberg, "Integrins," Cell and Tissue Research, vol. 339, no. 1, pp. 269-280, 2010.

[8] L. F. Reichardt and K. J. Tomaselli, "Extracellular matrix molecules and their receptors: functions in neural development," Annual Review of Neuroscience, vol. 14, pp. 531-570, 1991.

[9] R. S. Schmid and E. S. Anton, "Role of integrins in the development of the cerebral cortex," Cerebral Cortex, vol. 13, no. 3, pp. 219-224, 2003.

[10] R. S. Schmid, S. Shelton, A. Stanco, Y. Yokota, J. A. Kreidberg, and E. S. Anton, " $\alpha 3 \beta 1$ integrin modulates neuronal migration and placement during early stages of cerebral cortical development," Development, vol. 131, no. 24, pp. 6023-6031, 2004.

[11] E. Georges-Labouesse, M. Mark, N. Messaddeq, and A. Gansmüller, "Essential role of $\alpha 6$ integrins in cortical and retinal lamination," Current Biology, vol. 8, no. 17, pp. 983-986, 1998.

[12] G. Marchetti, S. Escuin, A. van der Flier, A. de Arcangelis, R. O. Hynes, and E. Georges-Labouesse, "Integrin $\alpha 5 \beta 1$ is necessary for regulation of radial migration of cortical neurons during mouse brain development," European The Journal of Neuroscience, vol. 31, no. 3, pp. 399-409, 2010.

[13] D. S. Galileo, J. Majors, A. F. Horwitz, and J. R. Sanes, "Retrovirally introduced antisense integrin RNA inhibits neuroblast migration in vivo," Neuron, vol. 9, no. 6, pp. 1117-1131, 1992.

[14] C. Andressen, S. Adrian, R. Fässler, S. Arnhold, and K. Addicks, "The contribution of $\beta 1$ integrins to neuronal migration and differentiation depends on extracellular matrix molecules," European Journal of Cell Biology, vol. 84, no. 12, pp. 973-982, 2005.

[15] M. F. DeFreitas, C. K. Yoshida, W. A. Frazier, D. L. Mendrick, R. M. Kypta, and L. F. Reichardt, "Identification of integrin $\alpha 3 \beta 1$ as a neuronal thrombospondin receptor mediating neurite outgrowth," Neuron, vol. 15, no. 2, pp. 333-343, 1995.
[16] U. Muller, B. Bossy, K. Venstrom, and L. F. Reichardt, "Integrin $\alpha 8 \beta 1$ promotes attachment, cell spreading, and neurite outgrowth on fibronectin," Molecular Biology of the Cell, vol. 6, no. 4, pp. 433-448, 1995.

[17] R. Belvindrah, D. Graus-Porta, S. Goebbels, K. A. Nave, and U. Müller, " $\beta 1$ integrins in radial glia but not in migrating neurons are essential for the formation of cell layers in the cerebral cortex," The Journal of Neuroscience, vol. 27, no. 50, pp. 13854-13865, 2007.

[18] R. Fassler and M. Meyer, "Consequences of lack of $\beta 1$ integrin gene expression in mice," Genes and Development, vol. 9, no. 15, pp. 1896-1908, 1995.

[19] D. Graus-Porta, S. Blaess, M. Senften et al., “ $\beta 1$-class integrins regulate the development of laminae and folia in the cerebral and cerebellar cortex," Neuron, vol. 31, no. 3, pp. 367-379, 2001.

[20] E. Förster, A. Tielsch, B. Saum et al., "Reelin, disabled 1, and $\beta 1$ integrins are required for the formation of the radial glial scaffold in the hippocampus," Proceedings of the National Academy of Sciences of the United States of America, vol. 99, no. 20, pp. 13178-13183, 2002.

[21] A. Niewmierzycka, J. Mills, R. St.-Arnaud R., S. Dedhar, and L. F. Reichardt, "Integrin-linked kinase deletion from mouse cortex results in cortical lamination defects resembling cobblestone lissencephaly," The Journal of Neuroscience, vol. 25, no. 30, pp. 7022-7031, 2005.

[22] R. Belvindrah, P. Nalbant, S. Ding, C. Wu, G. M. Bokoch, and U. Müller, "Integrin-linked kinase regulates Bergmann glial differentiation during cerebellar development," Molecular and Cellular Neuroscience, vol. 33, no. 2, pp. 109-125, 2006.

[23] I. Nikonenko, N. Toni, M. Moosmayer, Y. Shigeri, D. Muller, and L. S. Jones, "Integrins are involved in synaptogenesis, cell spreading, and adhesion in the postnatal brain," Developmental Brain Research, vol. 140, no. 2, pp. 185-194, 2003.

[24] P. Liesi, I. Seppala, and E. Trenkner, "Neuronal migration in cerebellar microcultures is inhibited by antibodies against a neurite outgrowth domain of laminin," Journal of Neuroscience Research, vol. 33, no. 1, pp. 170-176, 1992.

[25] B. Zassler, C. Schermer, and C. Humpel, "Protein kinase C and phosphoinositol-3-kinase mediate differentiation or proliferation of slice-derived rat microglia," Pharmacology, vol. 67, no. 4, pp. 211-215, 2003.

[26] C. Schermer and C. Humpel, "Granulocyte macrophage-colony stimulating factor activates microglia in rat cortex organotypic brain slices," Neuroscience Letters, vol. 328, no. 2, pp. 180-184, 2002.

[27] E. M. Stettler and D. S. Galileo, "Radial glia produce and align the ligand fibronectin during neuronal migration in the developing chick brain," Journal of Comparative Neurology, vol. 468, no. 3, pp. 441-451, 2004.

[28] P. Liesi, D. Dahl, and A. Vaheri, "Laminin is produced by early rat astrocytes in primary culture," Journal of Cell Biology, vol. 96, no. 3, pp. 920-924, 1983.

[29] A. E. Aplin, A. Howe, S. K. Alahari, and R. L. Juliano, "Signal transduction and signal modulation by cell adhesion receptors: the role of integrins, cadherins, immunoglobulin-cell adhesion molecules, and selectins," Pharmacological Reviews, vol. 50, no. 2, pp. 197-263, 1998.

[30] R. L. Juliano, P. Reddig, S. Alahari, M. Edin, A. Howe, and A. Aplin, "Integrin regulation of cell signalling and motility," Biochemical Society Transactions, vol. 32, pp. 443-446, 2004.

[31] B. P. Eliceiri, "Integrin and growth factor receptor crosstalk," Circulation Research, vol. 89, no. 12, pp. 1104-1110, 2001. 
[32] D. A. Hsia, S. T. Lim, J. A. Bernard-Trifilo et al., "Integrin $\alpha 4 \beta 1$ promotes focal adhesion kinase-independent cell motility via $\alpha 4$ cytoplasmic domain-specific activation of c-Src," Molecular and Cellular Biology, vol. 25, no. 21, pp. 9700-9712, 2005.

[33] J. E. Bleasdale, N. R. Thakur, R. S. Gremban et al., "Selective inhibition of receptor-coupled phospholipase C-dependent processes in human platelets and polymorphonuclear neutrophils," Journal of Pharmacology and Experimental Therapeutics, vol. 255, no. 2, pp. 756-768, 1990.

[34] L. M. Gleeson, C. Chakraborty, T. Mckinnon, and P. K. Lala, "Insulin-like growth factor-binding protein 1 stimulates human trophoblast migration by signaling through $\alpha 5 \beta 1$ integrin via mitogen-activated protein kinase pathway," Journal of Clinical Endocrinology and Metabolism, vol. 86, no. 6, pp. 2484-2493, 2001.

[35] H. T. Ma, K. Venkatachalam, H. S. Li et al., "Assessment of the role of the inositol 1,4,5-trisphosphate receptor in the activation of transient receptor potential channels and store-operated $\mathrm{Ca}^{2+}$ entry channels," Journal of Biological Chemistry, vol. 276, no. 22, pp. 18888-18896, 2001.

[36] K. Hirai, H. Yoshioka, M. Kihara et al., "Inhibiting neuronal migration by blocking NMDA receptors in the embryonic rat cerebral cortex: a tissue culture study," Developmental Brain Research, vol. 114, no. 1, pp. 63-67, 1999.

[37] T. Ranta-Knuuttila, T. Kiviluoto, H. Mustonen et al., "Migration of primary cultured rabbit gastric epithelial cells requires intact protein kinase $\mathrm{C}$ and $\mathrm{Ca}^{2+} /$ calmodulin activity," Digestive Diseases and Sciences, vol. 47, no. 5, pp. 1008-1014, 2002.

[38] M. Phillippe and A. Basa, "The effects of ruthenium red, an inhibitor of calcium-induced calcium release, on phasic myometrial contractions," Biochemical and Biophysical Research Communications, vol. 221, no. 3, pp. 656-661, 1996.

[39] N. Maeda and M. Noda, "Involvement of receptor-like protein tyrosine phosphatase $\zeta / \mathrm{RPTP} \beta$ and its ligand pleiotrophin/ heparin-binding growth-associated molecule (HB-GAM) in neuronal migration," Journal of Cell Biology, vol. 142, no. 1, pp. 203-216, 1998.

[40] U. K. Rout and J. M. Dhossche, "Liquid-diet with alcohol alters maternal, fetal and placental weights and the expression of molecules involved in integrin signaling in the fetal cerebral cortex," International Journal of Environmental Research and Public Health, vol. 7, no. 11, pp. 4023-4036, 2010.

[41] J. Aarum, K. Sandberg, S. L. B. Haeberlein, and M. A. A. Persson, "Migration and differentiation of neural precursor cells can be directed by microglia," Proceedings of the National Academy of Sciences of the United States of America, vol. 100, no. 26, pp. 15983-15988, 2003.

[42] J. Segarra, L. Balenci, T. Drenth, F. Maina, and F. Lamballe, "Combined signaling through ERK, PI3K/AKT, and RAC1/p38 is required for met-triggered cortical neuron migration," Journal of Biological Chemistry, vol. 281, no. 8, pp. 4771-4778, 2006.

[43] P. R. Borghesani, J. M. Peyrin, R. Klein et al., "BDNF stimulates migration of cerebellar granule cells," Development, vol. 129, no. 6, pp. 1435-1442, 2002.

[44] D. L. Mendrick and D. M. Kelly, “Temporal expression of VLA2 and modulation of its ligand specificity by rat glomerular epithelial cells in vitro," Laboratory Investigation, vol. 69, no. 6, pp. 690-702, 1993.

[45] T. A. Ferguson and T. S. Kupper, "Antigen-independent processes in antigen-specific immunity: a role for $\alpha 4$ integrin," Journal of Immunology, vol. 150, no. 4, pp. 1172-1182, 1993.
[46] G. T. van Nhieu and R. R. Isberg, "The Yersinia pseudotuberculosis invasin protein and human fibronectin bind to mutually exclusive sites on the $\alpha 5 \beta 1$ integrin receptor," Journal of Biological Chemistry, vol. 266, no. 36, pp. 24367-24375, 1991.

[47] K. Moulder, K. Roberts, E. M. Shevach, and J. E. Coligan, "The mouse vitronectin receptor is a T cell activation antigen," Journal of Experimental Medicine, vol. 173, no. 2, pp. 343-347, 1991.

[48] M. Aumailley, R. Timpl, and A. Sonnenberg, "Antibody to integrin $\alpha 6$ subunit specifically inhibits cell-binding to laminin fragment 8," Experimental Cell Research, vol. 188, no. 1, pp. 55-60, 1990.

[49] G. F. Burns, L. Cosgrove, and T. Triglia, "The IIb-IIIa glycoprotein complex that mediates platelet aggregation is directly implicated in leukocyte adhesion," Cell, vol. 45, no. 2, pp. 269-280, 1986.

[50] E. A. Wayner, W. G. Carter, R. S. Piotrowicz, and T. J. Kunicki, "The function of multiple extracellular matrix receptors in mediating cell adhesion to extracellular matrix: preparation of monoclonal antibodies to the fibronectin receptor that specifically inhibit cell adhesion to fibronectin and react with platelet glycoproteins Ic-IIa," Journal of Cell Biology, vol. 107, no. 5, pp. 1881-1891, 1988.

[51] U. K. Rout, "Valproate, thalidomide and ethyl alcohol alter the migration of HTR-8/SVneo cells," Reproductive Biology and Endocrinology, vol. 4, article 44, 2006.

[52] N. Maitra, I. L. Flink, J. J. Bahl, and E. Morkin, "Expression of $\alpha$ and $\beta$ integrins during terminal differentiation of cardiomyocytes," Cardiovascular Research, vol. 47, no. 4, pp. 715-725, 2000.

[53] M. L. Feltri, M. Arona, S. S. Scherer, and L. Wrabetz, "Cloning and sequence of the cDNA encoding the $\beta 4$ integrin subunit in rat peripheral nerve," Gene, vol. 186, no. 2, pp. 299-304, 1997.

[54] M. L. Condic and P. C. Letourneau, "Ligand-induced changes in integrin expression regulate neuronal adhesion and neurite outgrowth," Nature, vol. 389, no. 6653, pp. 852-856, 1997.

[55] S. P. Palecek, J. C. Loftust, M. H. Ginsberg, D. A. Lauffenburger, and A. F. Horwitz, "Integrin-ligand binding properties govern cell migration speed through cell-substratum adhesiveness," Nature, vol. 385, no. 6616, pp. 537-540, 1997.

[56] R. P. Tucker, J. K. Brunso-Bechtold, D. A. Jenrath et al., "Cellular origins of tenascin in the developing nervous system," Perspectives on Developmental Neurobiology, vol. 2, no. 1, pp. 89-99, 1994.

[57] D. Seiffert, M. L. Iruela-Arispe, E. H. Sage, and D. J. Loskutoff, "Distribution of vitronectin mRNA during murine development," Developmental Dynamics, vol. 203, no. 1, pp. 71-79, 1995.

[58] J. H. McCarty, A. Lacy-Hulbert, A. Charest et al., "Selective ablation of $\alpha \mathrm{v}$ integrins in the central nervous system leads to cerebral hemorrhage, seizures, axonal degeneration and premature death," Development, vol. 132, no. 1, pp. 165-176, 2005.

[59] H. Schottelndreier, B. V. Potter, G. W. Mayr, and A. H. Guse, "Mechanisms involved in alpha6beta1-integrin-mediated $\mathrm{Ca}(2+)$ signalling," Cellular Signalling, vol. 13 , no. 12, pp. 895-899, 2001.

[60] K. Fukami, S. Inanobe, K. Kanemaru, and Y. Nakamura, "Phospholipase $\mathrm{C}$ is a key enzyme regulating intracellular calcium and modulating the phosphoinositide balance," Progress in Lipid Research, vol. 49, no. 4, pp. 429-437, 2010. 
[61] J. H. Choi, Y. R. Yang, S. K. Lee et al., "Phospholipase C- $\gamma 1$ potentiates integrin-dependent cell spreading and migration through Pyk2/paxillin activation," Cellular Signalling, vol. 19, no. 8, pp. 1784-1796, 2007.

[62] C. Larsson, "Protein kinase $\mathrm{C}$ and the regulation of the actin cytoskeleton," Cellular Signalling, vol. 18, no. 3, pp. 276-284, 2006.

[63] J. Q. Zheng and M. M. Poo, "Calcium signaling in neuronal motility," Annual Review of Cell and Developmental Biology, vol. 23, pp. 375-404, 2007.

[64] X. Zhang, A. Chattopadhyay, Q. S. Ji et al., "Focal adhesion kinase promotes phospholipase C- $\gamma 1$ activity," Proceedings of the National Academy of Sciences of the United States of America, vol. 96, no. 16, pp. 9021-9026, 1999.

[65] N. P. Jones, J. Peak, S. Brader, S. A. Eccles, and M. Katan, “PLC $\gamma 1$ is essential for early events in integrin signalling required for cell motility," Journal of Cell Science, vol. 118, pp. 2695-2706, 2005.

[66] L. Zhou, Y. Jossin, and A. M. Goffinet, "Identification of small molecules that interfere with radial neuronal migration and early cortical plate development," Cerebral Cortex, vol. 17, no. 1, pp. 211-220, 2007.

[67] C. T. Zhao, K. Li, J. T. Li et al., "PKC $\delta$ regulates cortical radial migration by stabilizing the Cdk5 activator $\mathrm{p} 35$," Proceedings of the National Academy of Sciences of the United States of America, vol. 106, no. 50, pp. 21353-21358, 2009.

[68] T. Ng, D. Shima, A. Squire et al., "PKC $\alpha$ regulates $\beta 1$ integrindependent cell motility through association and control of integrin traffic," The EMBO Journal, vol. 18, no. 14, pp. 3909-3923, 1999.

[69] N. Alam, H. L. Goel, M. J. Zarif et al., "The integrin-growth factor receptor duet," Journal of Cellular Physiology, vol. 213, no. 3, pp. 649-653, 2007.

[70] A. Umesh, M. A. Thompson, E. N. Chini, K. P. Yip, and J. S. K. Sham, "Integrin ligands mobilize $\mathrm{Ca}^{2+}$ from ryanodine receptor-gated stores and lysosome-related acidic organelles in pulmonary arterial smooth muscle cells," Journal of Biological Chemistry, vol. 281, no. 45, pp. 34312-34323, 2006.

[71] E. T. O’Brien, E. D. Salmon, and H. P. Erickson, "How calcium causes microtubule depolymerization," Cell Motility and the Cytoskeleton, vol. 36, no. 2, pp. 125-135, 1997.

[72] R. J. Pasterkamp, J. J. Peschon, M. K. Spriggs, and A. L. Kolodkin, "Semaphorin 7A promotes axon outgrowth through integrins and MAPKs," Nature, vol. 424, no. 6947, pp. 398-405, 2003. 

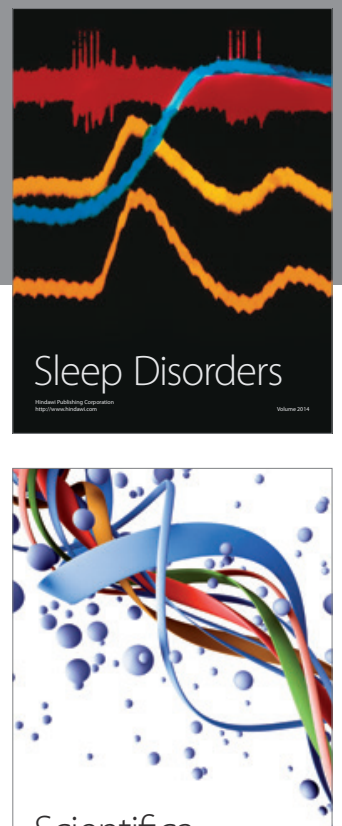

Scientifica
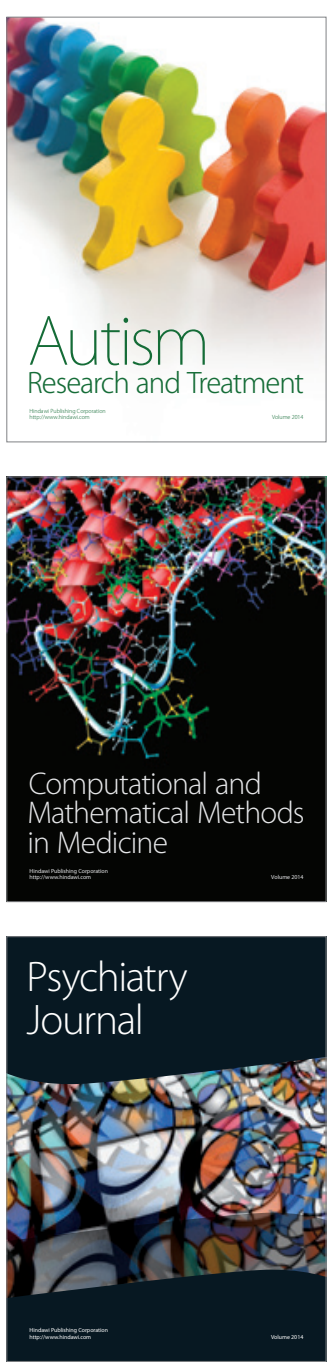
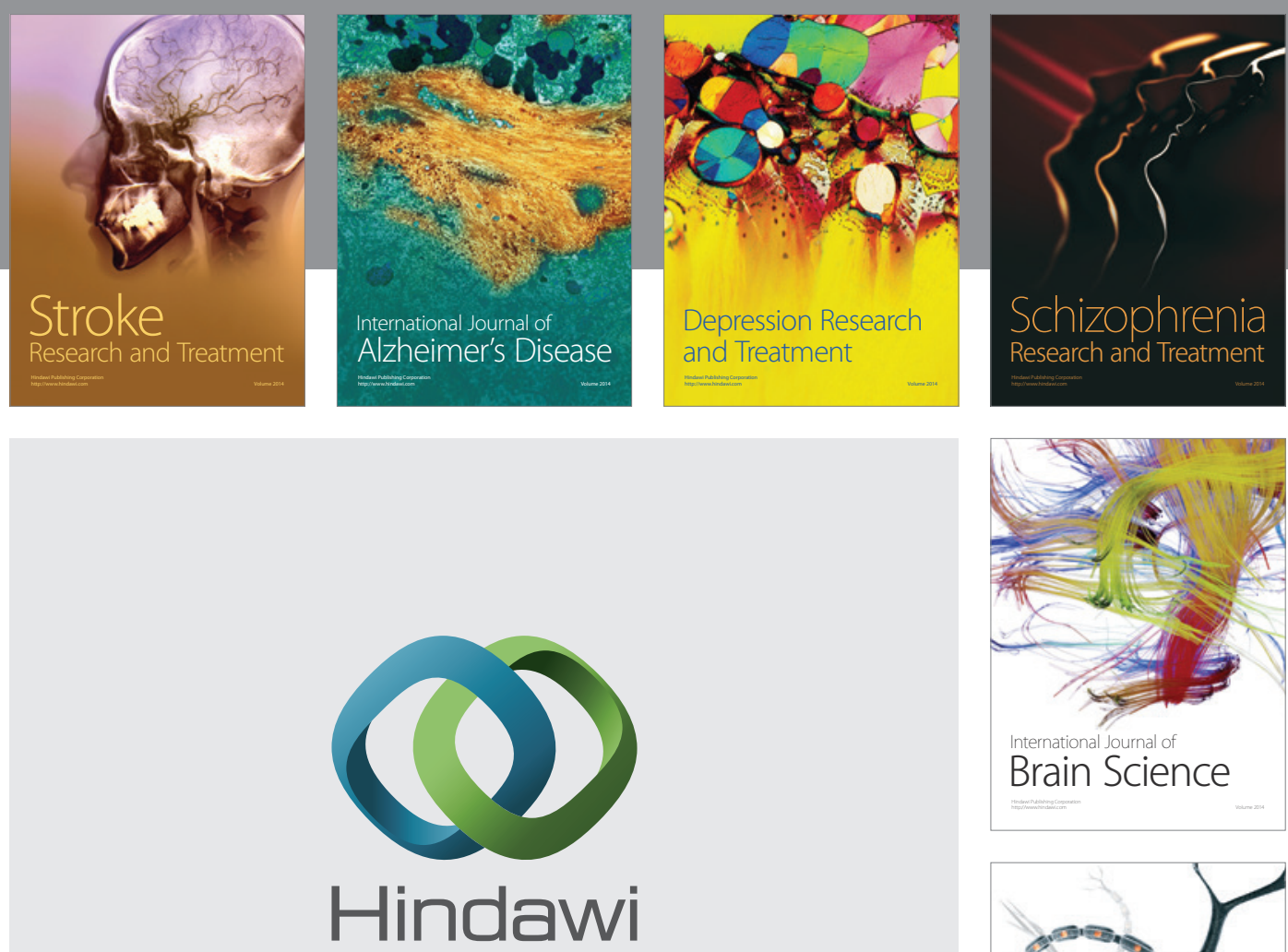

Submit your manuscripts at

http://www.hindawi.com
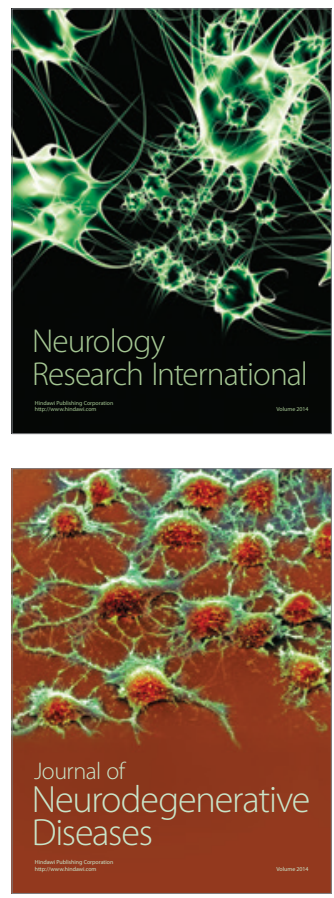

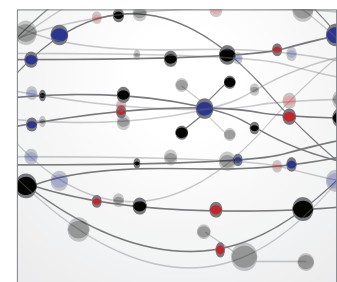

The Scientific World Journal
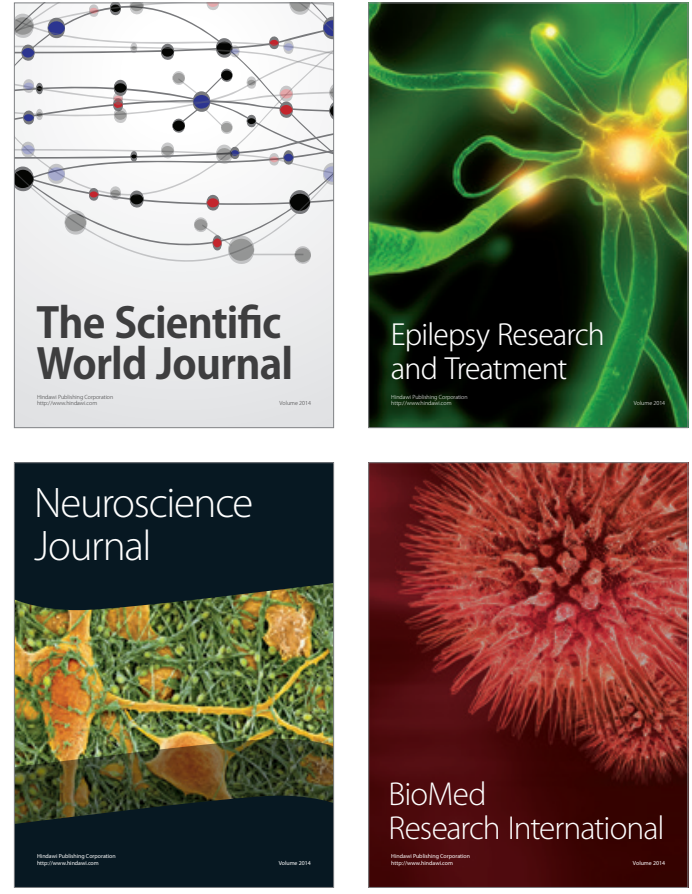

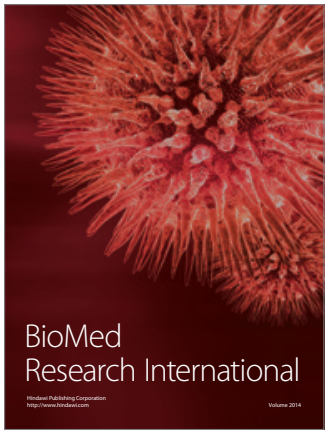

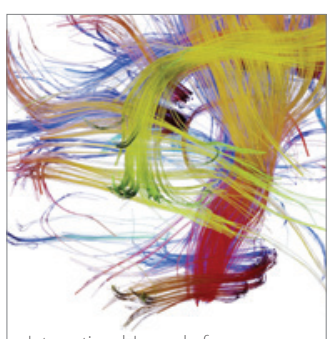

Brain Science

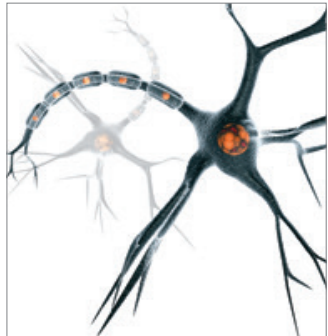

Neural Plasticity
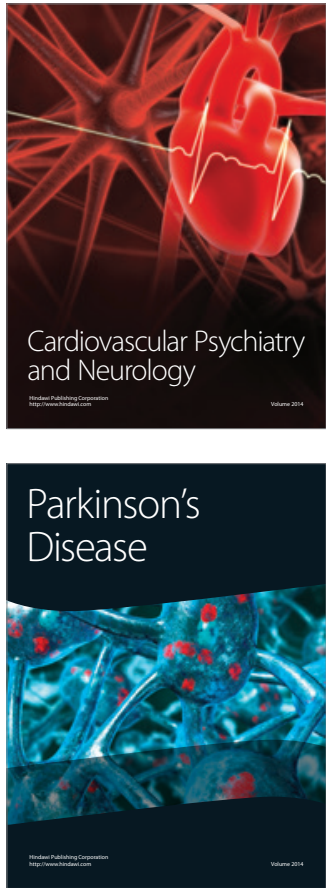